\title{
Article \\ Benefits and Risks of the Technological Creep of LED Light Technologies Applied to the Purse Seine Fishery
}

\author{
Pasquale Ricci ${ }^{1,2, *(D)}$, Nicola Trivellin ${ }^{3}$, Daniela Cascione ${ }^{1}$, Giulia Cipriano ${ }^{1}\left(\mathbb{D}\right.$, Viviana Teresa Orlandi ${ }^{4}(\mathbb{D})$ and \\ Roberto Carlucci ${ }^{1,2}$
}

check for updates

Citation: Ricci, P.; Trivellin, N.; Cascione, D.; Cipriano, G.; Orlandi, V.T.; Carlucci, R. Benefits and Risks of the Technological Creep of LED Light Technologies Applied to the Purse Seine Fishery. Biology 2022, 11, 48 https://doi.org/10.3390/biology 11010048

Academic Editor: John R. Turner

Received: 5 November 2021

Accepted: 22 December 2021

Published: 29 December 2021

Publisher's Note: MDPI stays neutral with regard to jurisdictional claims in published maps and institutional affiliations.

Copyright: (C) 2021 by the authors. Licensee MDPI, Basel, Switzerland. This article is an open access article distributed under the terms and conditions of the Creative Commons Attribution (CC BY) license (https:// creativecommons.org/licenses/by/ $4.0 /)$.
1 Department of Biology, University of Bari, Via E. Orabona 4, 70124 Bari, Italy; daniela.cascione@uniba.it (D.C.); giulia.cipriano@uniba.it (G.C.); roberto.carlucci@uniba.it (R.C.)

2 CoNISMa, Piazzale Flaminio 9, 00196 Rome, Italy

3 Department of Industrial Engineering, University of Padova, Via Venezia 1, 35131 Padova, Italy; nicola.trivellin@unipd.it

4 Department of Bioscience and Life Science, University of Insubria, Via J-H Dunant 3, 21100 Varese, Italy; viviana.orlandi@uninsubria.it

* Correspondence: pasquale.ricci@uniba.it

Simple Summary: The purse seine (PS) fishery with lamps is one of the most effective fishing techniques in the Mediterranean Sea, targeting phototactic organisms, such as anchovies and sardines. However, the employment of high-power lamps for many hours to aggregate fish schools involves an increase in costs for fuel and negative consequences on the environment. In this study, the catch efficiency of LED light technology was compared to the traditional incandescent lamp employed in the PS fishery in the Adriatic Sea. Three LED lights (white, blue, and pulsing) were compared with the incandescent lamp for catch efficiency, energy and hourly fuel consumption, $\mathrm{CO}_{2}$ emissions, and economic costs. The white LED increased efficiency by more than 2 times per unit of energy and fuel consumption, while the pulsing LED and blue LED increased efficiency by about 6 and 9 times, respectively. The $\mathrm{CO}_{2}$ emissions were reduced by approximately 2 and 8 times with white and blue LEDs, respectively. The potential positive economic impacts derived from the LED technology on the PS fishery in terms of fuel cost-saving percentages were all higher than $60 \%$. This technology shows the potential economic benefits for fishermen and the mitigation of negative effects on the environment.

\begin{abstract}
This study is a first attempt to investigate the catch efficiency of LED light technology compared to the traditional incandescent lamp that is used in the purse seine fishery (PS) in the Central Adriatic Sea (Mediterranean Sea). Catches per unit effort were adopted to assess the performance of lighting systems, considering the electrical energy and the fuel consumption as effort units. Concerning the catch efficiency, the white LED, which emits the same light spectra as the incandescent lamp, increased the yield by over 2 times per consumption unit of energy and fuel. The yield efficiency increased up to approximately 6 and 9 times when adopting the pulsing white or blue LED, respectively. These increases were due to the energy savings resulting from the flashing of the white LED or by the greater water penetration of the blue LED. No significant difference in target species sizes was detected between the use of LEDs and the incandescent lamp. The results obtained from estimates of the hourly fuel consumption and $\mathrm{CO}_{2}$ emissions stress potential benefits in the reduction of the carbon footprint due to the use of LEDs within the PS fishery. Positive economic impacts were derived from the LED technology on the PS fishery, with the fuel cost-saving percentages all being higher than $60 \%$. The LED technology clearly shows potential benefits at the economic level for the fishermen, and the possibility of mitigating indirect negative effects on the environment due to fuel combustion and greenhouse gas emissions. On the other hand, the application of new technology that improves the catch efficiency of fishing gears should be carefully considered. The lack of regulations controlling technological advancement could cause unwanted long-term effects.
\end{abstract}


Keywords: anchovy; $\mathrm{CO}_{2}$ emissions; $\mathrm{CPUE}$; fishery sustainability; light emitting diode (LED)

\section{Introduction}

The sustainable management of fishing stocks is a fundamental point to maximize the benefits provided by the fishery, while aiming to reduce anthropic impacts on marine ecosystems, as well as to increase economic growth and social welfare [1-5]. In particular, the ecosystem-based fishery management approach (EBFM, [6]) requires a move from the traditional management strategy, focused on preventing species populations from declining, towards the conservation of ecosystems in a healthy, productive, and resilient condition so they can provide the services useful for human life. In this regard, it is necessary to consider additional elements in a holistic pathway, such as interactions with other species, the effects of environmental changes, or pollution and other stressors on habitat and water quality. The great challenge of this approach is due to the high complexity derived from interactions between environmental phenomena, technological aspects, and socio-economic problems, as well as the uncertainties in the assessment of stochastic processes related to the exploited populations. Therefore, the need to add the human dimension to environmental goals has become urgent in the EBFM approach, requiring the use of indicators able to assess the performance of the fishing exploitation technique, integrated with ecological, social, and economic aspects [7]. From this point of view, the performance of fishing gears is closely related to their catch efficiency and fishing effort, which have increased over time because of technological progress (or technological creep), becoming a critical node in sustainabilityoriented fisheries management [8,9]. In fact, since the 1990s, a reconstruction of global catches has indicated a condition of decline, despite an increase in fishing effort and catch efficiency, with the consequence of causing overfishing conditions and unsustainable fisheries $[10,11]$. At the same time, the improvement in catch efficiency of fishing gears could represent a key element in moving the fishery towards a sustainable dimension. In this challenge, the building of knowledge on the performance of innovative fishing devices and regulations required for effective fishery management should be realized according to the EBFM approach [12].

Within the EBFM framework, the understanding of relationships between the technological advancement and the catch efficiency of fishing gears has become a priority [13], as well as the integrated assessment of negative impacts on fishing stocks and the environment, such as from fuel consumption and emission of greenhouse gases (GHG) [14,15]. In this research field, an exemplary case is represented by the purse seine (PS) fishery operating with lamps to gather positive phototactic organisms (fishes and cephalopods), which is one of the most effective fishing techniques at the global scale [16,17]. This fishing technique is characterized by the involvement of a main vessel equipped with a purse seine net and smaller boats with lamps to attract fish during the night [18-20]. High-power lamps illuminate the fishing zone for many hours, aggregating the schooling fish, which are then encircled by the purse seine net. Therefore, expensive costs in fuel are involved in providing energy for the lamps, with the consequence of not being sustainable for the environment [21,22]. Historically, this technique used incandescent, fluorescent, halogen, and metal halide lamps because of their high luminant efficiency [23]. Since the 2000s, in southeast Asian countries, light emitting diode (LED) technology has been applied to the PS fishery instead of traditional lamps [17]. The LED lamp is a type of semiconductor diode lamp with direct current, and can be illuminated in a variety of colours that emit incoherent monochromatic light when given a forward voltage [24]. LED performance in terms of environmental impact, energy consumption rates, and fuel costs is much more advantageous than those of other lamps, thanks to its maximum illumination power combined with minimum energy consumption, long lifespan, high efficiency, better chromatic performance, and reduced environmental impact [25-27]. Other applications of LED technology have been tested for the fisheries in African lakes with similar results $[28,29]$. 
In the Mediterranean Sea, PS fishing gear with the incandescent light is widely used for catching small pelagic fishes, such as the anchovy (Engraulis encrasicolus, Engraulidae) and the sardine (Sardina pilchardus, Clupeidae) [30-32]. These target species are highly exploited in the Adriatic Sea (central Mediterranean Sea), where the PS fleet contributes a large proportion of their catches, together with midwater pelagic pair trawlers [33-36]. To date, the use of LED technology in the Mediterranean PS fleets is not widespread and little information is reported on its catch efficiency. Some studies have been carried out on the application of LEDs on demersal fishing gears to reduce the bycatch $[17,37,38]$, or to harvest commercial species in a lake [39]. However, an assessment of the catch efficiency and of the environmental impacts of incandescent lamps and alternative lighting technology has never been carried out.

Therefore, this study is a first attempt to investigate the catch efficiency of LED light technology compared to the traditional incandescent lamp in the Adriatic PS fishery. In particular, the performance of three different LED modules (white light, blue light, and pulsing light) was assessed using several efficiency and consumption indicators, and differences in the catch size composition were also explored. Fishery management aspects of LED performance in terms of benefits and potential risks are discussed.

\section{Materials and Methods}

\subsection{Study Area}

The Central Adriatic Sea in the Mediterranean Sea (FAO GFCM, Geographical Sub Area, GSA 17) is characterised by shallow waters not exceeding $100 \mathrm{~m}$ in depth, except for three depressions known as the Pomo/Jabuka Pits, ranging between 225 and $270 \mathrm{~m}$ in depth with a west-east progression [40]. The just-described seabed configuration allows the cold waters formed in the Northern Adriatic Sea to flow southwards and to descend into the depths of these pits, which results in ineffective water circulation and nutrient transport [41]. The area is characterised by high river inputs, which increase the productivity of the coastal waters and lower the salinity. The coasts are typically shallow and alluvial; in fact, the explored area does not exceed $200 \mathrm{~m}$ in depth. This area is a valuable fishing ground, where resources are mainly exploited by Italy and Croatia, with different fishing techniques, from trawling to purse seine [32,42]. In particular, year-round trawl and purse seine fisheries are conducted on anchovies and sardines by the Italian fleet in the Adriatic Sea, accounting for about $30 \%$ of the national catches $[43,44]$. The basin represents a relevant spawning area for the stocks of these small pelagic species [45-47], which are affected by changes in climate and water circulation [48-50].

The experimental survey was mainly conducted within GSA 17, an exploited area which extends to 60 miles off the Ortona Maritime Compartment, which was investigated through experimental trials (Figure 1). Only two experimental trials were carried out in the Southern Adriatic Sea (GSA 18) off the coast of the Gulf of Manfredonia because of bad weather conditions in GSA 17. 


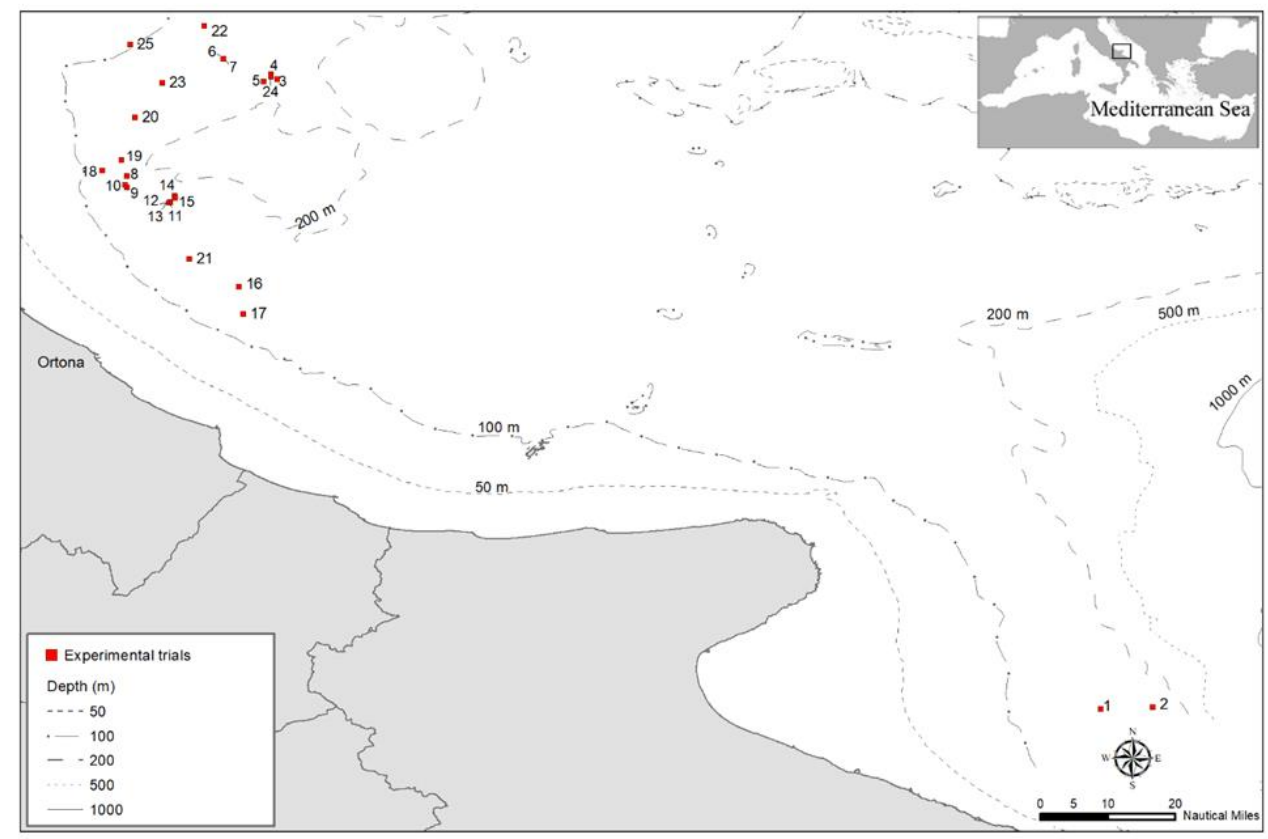

Figure 1. Map of the experimental trials carried out during the experimental survey from September to October 2020 in the Central and Southern Adriatic Sea (GSA 17 and 18).

\subsection{Features of LED Lighting Systems and the Incandescent Lamp}

Three types of LED light sources were development for the field experiment: white light (LWH) with a broad spectrum perceived as white, blue light (LBLU) with an emission which peaked in the $400-500 \mathrm{~nm}$ range, and a pulsing white light (PULSE) (Figure 2a,b). The LED lamps were designed to achieve the following objectives: (i) the luminous flux of the LED lamps should be similar to the output flux of traditional incandescent light sources; (ii) the light sources should be powered by alternate current (AC) or direct current (DC) with a voltage of 16-42 VAC; (iii) the light sources should each have a luminous flux which quadratically increases as a function of the supplied voltage. The LED light sources were subdivided into modular elements to allow for easier manufacturing and installation. High-power LEDs based on indium gallium nitride converted by means of phosphors were used to ensure the thermal stability of the lighting system. The LWH and LBLU modules were designed in the laboratory, and each module was equipped with a microcontroller to allow the calibration of the light output and ensure functional safety features. The PULSE light source was made using LWH hardware with a firmware update allowing a switch-on time of $50 \mathrm{~ms}$ and a total lighting period of $100 \mathrm{~ms}$. Each LWH and LBLU module had $800 \mathrm{~W}$ of electrical power at the maximum voltage of $42 \mathrm{VAC}$, corresponding to a current of approximately $19 \mathrm{~A}$, while the PULSE module had an average power of $400 \mathrm{~W}$ due to its $50 \%$ duty cycle. The following configurations were installed on the small boats: $\mathrm{LWH}$ with 12 modules, LBLUE and PULSE both with 3 modules. Dissimilarly, the incandescent lighting system (INC) was characterised by 20 lamps with a maximum power of $1000 \mathrm{~W}$ each. The LWH was designed to achieve a similar luminous flux to that of the INC light sources, while the LBLU was designed to have a similar radiative flux (optical power), in the $400-500 \mathrm{~nm}$ range, to the $\mathrm{LWH}$ in its entire spectrum. In all the systems, the luminous emission was adjusted by varying the input voltage provided by the motor-generator. The electrical behaviour of the LED modules was controlled by means of the firmware installed on the microcontroller of the module; its characteristic performance followed an Ohmic law of resistance. The value of the equivalent resistance for the LED modules was set to $2 \Omega$ to achieve a similar optical behaviour to that of the INC counterpart. 

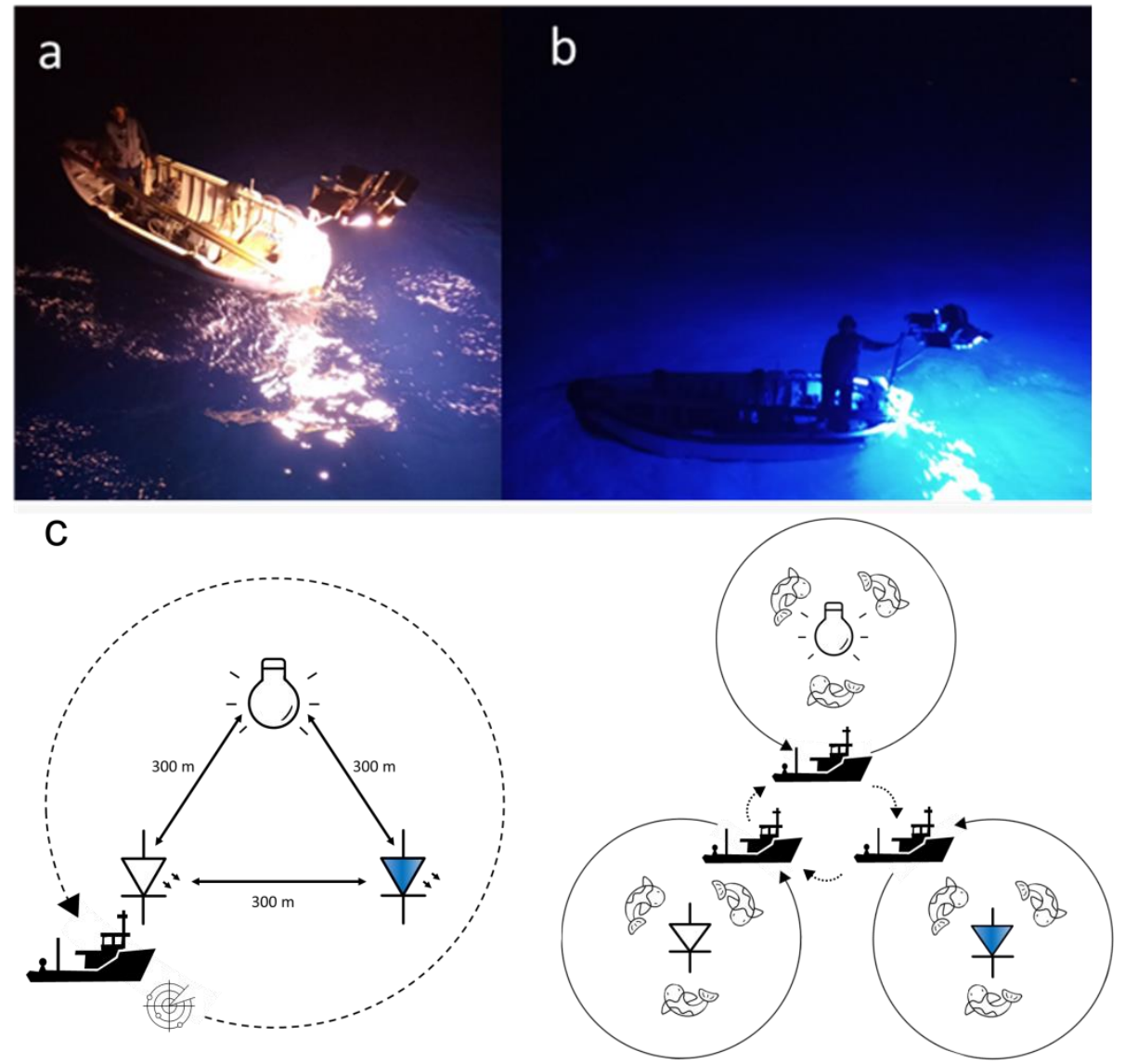

Figure 2. LEDs (a) white LED light, (b) blue LED light, and (c) outline of fishing operations conducted during experimental trials.

\subsection{Experimental Survey, Data Collection, and Treatment}

The experimental field survey for the comparative analysis between the LEDs and the INC lamp was carried out using a commercial PS vessel in September and October 2020, with nocturnal trials conducted from 6 p.m. until 7 a.m. the following day. The PS vessel (or mother vessel: length over all $28.46 \mathrm{~m}$; gross tonnage $133 \mathrm{t}$; engine power $800 \mathrm{~kW}$ ) carried three small boats on board, each equipped with one of the lighting systems. In addition, the mother vessel was equipped with a purse seine net with a length of $437.3 \mathrm{~m}$, a height of $189 \mathrm{~m}$, and a stretched mesh size of $18 \mathrm{~mm}$. Regarding the use of lighting systems on the three boats, the LWH and the INC lamp were used throughout the survey, while the LBLU system was used during September, and it was replaced by the PULSE in October.

During each experimental trial, the fishing operations were characterized by several steps starting from the search for schools of fish using sonar. Once a school of fish had been identified, three small boats, each equipped with a lighting system, were released into the fishing area. The small boats were positioned with their lights on at about $300 \mathrm{~m}$ from each other, beginning a phase of aggregation of the school of fish attracted by the lights (Figure 2c). This distance avoided reciprocal influence between the lighting systems of the three boats. After a sufficient aggregation time of the schools under each boat, monitored with sonar by the mother vessel, the operation of encircling and capturing each school of fish began. Specifically, the mother vessel surrounded a single boat by lowering the net and hauling the catch on board. Subsequently, this operation was repeated for the other two boats concluding the experimental trial. Data on the geographic position, the depth, marine weather conditions, start and end times of each trial, the time activity of each lamp with relative voltages and the catches by species (in biomass, $\mathrm{kg}$ ) were collected by the research personnel on board (Tables 1 and A1). Moreover, in order to investigate the size selectivity 
within catches obtained by each lighting system, samples of the harvested species were collected.

Table 1. Total catches $(\mathrm{kg})$ by species from 22 experimental trials (Tr.) obtained using all light systems: white LED (LWH), blue (LBLU), incandescent lamp (INC), and pulsing LED (PULSE). Species are indicated by FAO code: E. encrasicolus (ANE), S. colias (MAS), Illexcoindetii (SQM), S. pilchardus (PIL), Xiphias gladius (SWO), Sarda sarda (BON), and Trachurus mediterraneus (HMM).

\begin{tabular}{|c|c|c|c|c|c|c|c|c|c|c|}
\hline Tr. & Species & LWH & LBLU & INC & Tr. & Species & LWH & LBLU & INC & PULSE \\
\hline 1 & ANE & 474 & & 316 & 15 & ANE & 586 & 654 & 559 & \\
\hline 1 & MAS & 129 & & 87 & 15 & MAS & 6 & 7 & 5 & \\
\hline 1 & SQM & 3 & & 3 & 15 & PIL & 6 & 6 & 6 & \\
\hline 2 & MAS & 112 & & 73 & 15 & SQM & 6 & 6 & 5 & \\
\hline 2 & ANE & 434 & & 252 & 16 & ANE & 700 & 1681 & 420 & \\
\hline 2 & SQM & 14 & & 7 & 16 & MAS & 17 & 41 & 10 & \\
\hline 3 & ANE & 755 & & 247 & 16 & SQM & 2 & 4 & 1 & \\
\hline 3 & MAS & 7 & & 2 & 17 & ANE & 283 & 420 & 274 & \\
\hline 3 & SQM & 7 & & 3 & 17 & MAS & 7 & 9 & 6 & \\
\hline 4 & MAS & 13928 & & 13,321 & 18 & ANE & 2100 & & 560 & 1400 \\
\hline 5 & MAS & 5438 & & 5185 & 18 & MAS & 7 & & 2 & 2 \\
\hline 6 & ANE & 6478 & 3239 & 3220 & 18 & SQM & 7 & & 2 & 2 \\
\hline 6 & SWO & 73 & & & 19 & ANE & 5250 & & 1960 & 8400 \\
\hline 7 & ANE & 3543 & 2814 & 2716 & 19 & SQM & 7 & & 3 & 11 \\
\hline 8 & ANE & 1910 & 1751 & 1645 & 20 & ANE & 2002 & & 3003 & 2695 \\
\hline 8 & MAS & 41.1 & 37.6 & 35.4 & 21 & ANE & 1600 & & & 1700 \\
\hline 8 & PIL & 3.9 & 3.7 & 3.4 & 21 & MAS & 280 & & & 284 \\
\hline 8 & HMM & 0.261 & 0.237 & 0.27 & 22 & ANE & 2880 & & & 2800 \\
\hline 8 & $\mathrm{BON}$ & 0.012 & & & 22 & MAS & 115 & & & 119 \\
\hline 9 & ANE & 654 & 598 & 617 & & & & & & \\
\hline 10 & ANE & 732 & 520 & 674 & & Total Catch $(\mathrm{kg})$ & $59,382.3$ & $17,145.5$ & $40,987.1$ & $17,413.0$ \\
\hline 11 & ANE & 5240 & 2096 & 3144 & & Catch $(\%)$ & 44 & 13 & 30 & 13 \\
\hline 12 & ANE & 786 & 687 & 491 & & Mean & 1263.5 & 714.4 & 999.7 & 1741.3 \\
\hline 13 & ANE & 901 & 501 & 582 & & Stand. Error & 365.39 & 201.38 & 359.96 & 818.45 \\
\hline 14 & ANE & 1798 & 1995 & 1495 & & $\begin{array}{l}\text { ANE Tot. Catch } \\
(\mathrm{kg})\end{array}$ & 39,106 & 16,956 & 22,175 & 16,975 \\
\hline 14 & MAS & 27 & 31 & 23 & & ANE Tot. Catch (\%) & 98 & 99 & 99 & 98 \\
\hline 14 & PIL & 17 & 23 & 17 & & & & & & \\
\hline 14 & SQM & 16 & 21 & 12 & & & & & & \\
\hline
\end{tabular}

In order to identify the most important target species, and to check for any anomalies in the experimental trials with respect to the usual catches by the PS vessel in the fishing area and period, monthly catch data and fishing days relative to 2019 were collected from the logbook provided by the fishermen (Table A2). In particular, anchovy was the main target species harvested in 2019, which showed a monthly landing value always above $60 \%$ of the total, with landings of approximately $44 \mathrm{t}$ and $63.5 \mathrm{t}$ in September and October, respectively (Figure 3). In addition, in these two months, the second important target species was the Atlantic chub mackerel (Scomber colias, Scombridae), with a percentage monthly landing of approximately $20-30 \%$.

A total of 22 experimental trials were carried out during the survey, in which the LWH was used 22 times, INC 20 times, LBLU 12 times, and PULSE 5 times. These differences were determined by meteorological and sea condition variability, moon phases, the type of species targeted during the fishing trials, and the occurrence of other purse seines in the fishing area. The catch efficiency of the different lighting systems was compared on the main target species of the PS fishery; thus, only experimental trials with the occurrence of anchovy were considered, with bycatch species excluded from the analysis (Table 1). Therefore, a total of 20 trials were selected for the statistical analysis, while two trials (numbers 4 and 5) were excluded because the catches were only represented by the Atlantic chub mackerel. Specifically, individuals of this species were attracted and harvested using 
a yellow light obtained by using a lower voltage (20-22 V) setting of LWH light and the incandescent lamp.

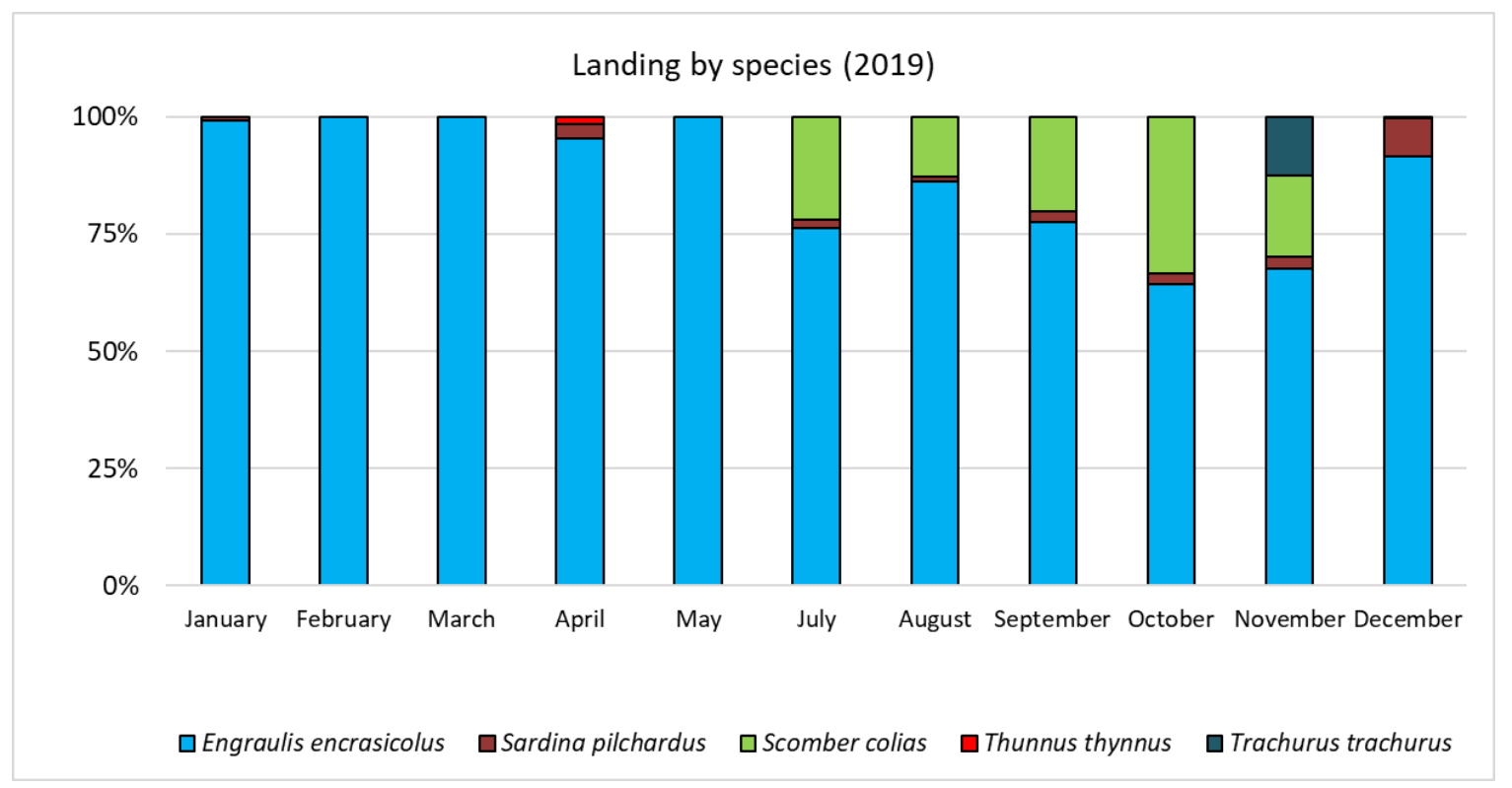

Figure 3. Monthly landings (\%) by species in 2019 in GSA 17 obtained from the PS vessel used in the experimental survey.

\subsection{Catch Efficiency of LED Lamps}

Catch per unit effort (CPUE) was adopted to assess the performance in catch efficiency of the lighting systems, considering electric energy consumption (kilowatts per hour, kWh) and fuel consumption (litre, L) as effort units. Therefore, CPUE values (median values and interquartile ranges, IR) were calculated as $\mathrm{kg} \mathrm{kWh}^{-1}$ and $\mathrm{kg} \mathrm{L}^{-1}$ (Table 2).

In order to detect differences in the size and age of the anchovy specimens sampled by each lighting system, total length (TL in $\mathrm{mm}$ ) was measured (Table A3), and the age (t) of each individual, reported as Age $0+, 1+, 2+, 3+$, and $4+$ (this latter also included individuals of ages older than 4), was calculated by means of the TL, adopting the Von Bertalanffy equation:

$$
T L=L_{\infty}\left(1-e^{-k\left(t-t_{0}\right)}\right)
$$

where $\mathrm{L}_{\infty}$ is the asymptotic length at which growth is zero, $\mathrm{k}$ is the growth rate, and $\mathrm{t}_{0}$ is the age at which the organisms would have had zero size. The growth parameters $\left(\mathrm{L}_{\infty}=18.61\right.$, $\left.\mathrm{K}=0.622, \mathrm{t}_{0}=-0.849\right)$ were obtained from the stock assessment of the E. encrasicolus in the Adriatic Sea [51].

Length-frequency distributions of each sample obtained using the investigated lighting systems were compared using the Kolmogorov-Smirnov test (D) [52]. Outliers (identified as TL values higher than the III quartile $+(1.5 \times \mathrm{IR}=$ interquartile range), or lower than the I quartile $-(1.5 \times \mathrm{IR})$, respectively) were removed before performing the $\mathrm{D}$ test, in order to reduce the noise in the analysis due to extreme values. In addition, the position of all catch in size with respect to the age of first maturity of the anchovy $(6-8 \mathrm{~cm},[51])$ was compared. The percentage of occurrence frequency $(\mathrm{F} \%)$ of specimens by age was calculated on the total number of sampled individuals. Differences in F\% for each age class were tested using the chi-squared test $\left(\chi^{2}\right)$, and a multiple comparison within and between lighting systems (post hoc analysis by $\mathrm{U}$ test) was applied through an absence-presence transformation ( 0 or 1 values, respectively) of the $\mathrm{F} \%$ data. 
Table 2. CPUE (energy, $\mathrm{kg} \mathrm{kWh}^{-1}$, and fuel consumption, $\mathrm{kg} \mathrm{L}^{-1}$ ), $\mathrm{CO}_{2}$ emissions ( $\mathrm{kg}$ ), and hourly fuel consumption $\left(\mathrm{L} \mathrm{h}^{-1}\right)$ by LWH, LBLU, PULSE, and INC estimated by 20 experimental trials (Tr.) used in the statistical analysis.

\begin{tabular}{|c|c|c|c|c|c|c|c|c|c|c|c|c|c|c|c|c|}
\hline \multirow[b]{2}{*}{ Tr. } & \multicolumn{4}{|c|}{ CPUE Energy } & \multicolumn{4}{|c|}{ CPUE Fuel } & \multicolumn{4}{|c|}{$\mathrm{CO}_{2}$ Emissions } & \multicolumn{4}{|c|}{ Hourly Fuel Consumption } \\
\hline & LWH & LBLU & INC & PULSE & LWH & LBLU & INC & PULSE & LWH & LBLU & INC & PULSE & LWH & LBLU & INC & PULSE \\
\hline 1 & 8.37 & & 4.22 & & 29.63 & & 14.93 & & 42.2 & & 55.9 & & 3.6 & & 7.1 & \\
\hline 2 & 13.28 & & 4.82 & & 47.02 & & 17.07 & & 24.4 & & 39.0 & & 3.1 & & 7.4 & \\
\hline 3 & 23.73 & & 4.20 & & 83.98 & & 14.88 & & 23.7 & & 43.8 & & 2.4 & & 7.4 & \\
\hline 6 & 101.47 & 207.88 & 23.80 & & 359.38 & 736.24 & 84.28 & & 47.6 & 11.6 & 100.9 & & 2.8 & 0.8 & 7.1 & \\
\hline 7 & 662.41 & 1573.73 & 204.56 & & 2346.36 & 5573.61 & 724.48 & & 4.0 & 1.3 & 9.9 & & 2.3 & 0.8 & 6.4 & \\
\hline 8 & 41.19 & 149.58 & 23.37 & & 163.16 & 529.75 & 23.37 & & 30.9 & 8.7 & 185.9 & & 2.5 & 0.7 & 19.4 & \\
\hline 9 & 45.39 & 204.68 & 21.97 & & 223.84 & 146.98 & 77.81 & & 7.7 & 10.7 & 20.9 & & 1.5 & 3.6 & 15.3 & \\
\hline 10 & 43.66 & 150.29 & 18.40 & & 154.62 & 532.29 & 65.15 & & 12.5 & 2.6 & 27.3 & & 2.6 & 0.5 & 20.7 & \\
\hline 11 & 111.44 & 215.77 & 31.74 & & 394.68 & 764.17 & 112.43 & & 35.1 & 7.2 & 73.8 & & 2.4 & 0.6 & 6.7 & \\
\hline 12 & 58.96 & 215.22 & 16.78 & & 208.86 & 763.33 & 59.44 & & 9.9 & 2.4 & 21.8 & & 4.8 & 0.7 & 14.6 & \\
\hline 13 & 83.37 & 126.84 & 29.42 & & 295.28 & 448.91 & 104.30 & & 8.1 & 2.9 & 14.7 & & 2.2 & 0.8 & 6.7 & \\
\hline 14 & 35.31 & 170.08 & 13.71 & & 125.06 & 602.35 & 48.54 & & 38.0 & 8.7 & 81.3 & & 2.8 & 0.7 & 8.3 & \\
\hline 15 & 30.01 & 164.31 & 18.39 & & 106.26 & 583.93 & 65.14 & & 14.6 & 3.0 & 22.7 & & 3.2 & 0.6 & 7.1 & \\
\hline 16 & 16.47 & 183.61 & 5.17 & & 58.34 & 650.30 & 18.32 & & 31.7 & 6.8 & 60.5 & & 3.0 & 0.6 & 7.1 & \\
\hline 17 & 19.87 & 120.69 & 16.45 & & 70.37 & 427.44 & 58.27 & & 10.6 & 2.6 & 12.4 & & 4.3 & 0.6 & 7.1 & \\
\hline 18 & 40.14 & & 12.39 & 73.61 & 142.15 & & 43.88 & 260.69 & 39.0 & & 33.7 & 14.2 & 2.6 & & 5.2 & 1.64 \\
\hline 19 & 86.81 & & 31.51 & 321.10 & 307.44 & & 111.60 & 1137.23 & 45.1 & & 46.4 & 19.5 & 2.2 & & 5.5 & 1.60 \\
\hline 20 & 139.03 & & 49.88 & 110.63 & 492.39 & & 176.67 & 391.82 & 10.7 & & 44.9 & 18.2 & 0.6 & & 5.6 & 1.68 \\
\hline 21 & 40.16 & & & 93.82 & 142.24 & & & 332.28 & 29.7 & & & 13.5 & 2.3 & & & 1.69 \\
\hline 22 & 184.62 & & & 259.26 & 653.85 & & & 918.21 & 11.6 & & & 8.1 & 2.4 & & & 1.66 \\
\hline Median & 42 & 177 & 18 & 111 & 159 & 593 & 62 & 392 & 29.1 & 5.9 & 50.0 & 17.1 & 2.9 & 0.7 & 7.7 & 1.7 \\
\hline IR & 62.04 & 59.60 & 15.30 & 165.44 & 219.73 & 233.48 & 70.80 & 585.93 & 38.41 & 8.94 & 59.75 & 12.21 & 0.81 & 0.18 & 4.50 & 0.00 \\
\hline Min & 8 & 121 & 4 & 74 & 30 & 147 & 15 & 261 & 12.9 & 3.1 & 26.6 & 16.3 & 0.6 & 0.6 & 5.6 & 1.7 \\
\hline $\operatorname{Max}$ & 662 & 1574 & 205 & 321 & 2346 & 5574 & 724 & 1137 & 57.5 & 14.0 & 224.6 & 23.6 & 8.0 & 3.8 & 34.5 & 2.0 \\
\hline
\end{tabular}

Differences in CPUE values between experimental LED lamps and the traditional incandescent lamp were compared using the Kruskal-Wallis test $(\mathrm{KW})$ and a nonparametric post hoc test, based on the Bonferroni-corrected pairwise Mann-Whitney test (U) [53]. This choice was due to the non-normal distribution of the data tested by the Shapiro-Wilk test (Table A4) [54]. The statistical analysis was carried out using PAST 4.03 [55].

\subsection{Energy Consumption and $\mathrm{CO}_{2}$ Emissions}

The electrical energy consumed by each LED module and the INC lamp was calculated using the electric power generated during the trial by each motor-generator on board the boats according to the equation:

$$
P(\text { Watt })=\frac{\mathrm{V}^{2}}{\mathrm{R}} \times \text { n.LED modules or INC lamps }
$$

where the voltage $(V)$ is measured on board, while the equivalent electric resistance $(R)$ was equal to $2.2 \Omega$ and $1.55 \Omega$ for LED modules and INC lamps, respectively. Thus, the total electric consumption (in $\mathrm{kWh}$ ) of each lighting system was calculated as the product of the electric power multiplied by the time of activity of each LED module or INC lamp (Table A5). The fuel consumption (diesel in L) was calculated for each tested lighting system as:

$$
\text { Fuel }=\frac{(\text { Electric consumption } \times 240)}{\text { fuel density }}
$$


where electric consumption is expressed in $\mathrm{kWh}$ and the diesel density is equal to $850 \mathrm{gr}$ $\mathrm{L}^{-1}$ (Table A5). In addition, comparisons between the consumption of each lamp in terms of electric energy consumption (kWh) and hourly fuel consumption $\left(\mathrm{L} \mathrm{h}^{-1}\right)$ were carried out, as the $\mathrm{CO}_{2}$ emissions generated by the fuel combustion during the fishing activity were also estimated (Table 2). According to the EPA (United States Environmental Protection Agency, https:/ / www.epa.gov/, accessed on 25 September 2021) [56], $1 \mathrm{~L}$ of diesel (of density of $835 \mathrm{gr} \mathrm{L}^{-1}$, [57]) contains $720 \mathrm{gr}(86.2 \%)$ of carbon requiring $1920 \mathrm{gr}$ of oxygen for its combustion ( $1: 2$ stoichiometric ratio). Therefore, approximately $2.64 \mathrm{~kg}$ of $\mathrm{CO}_{2}$ is released into the atmosphere by every $1 \mathrm{~L}$ of diesel burnt.

Finally, an estimate of the economic costs of each lighting system during fishing activities was assessed using hourly fuel consumption with three different fuel prices (Euro per litre, EURL ${ }^{-1}$ ): average price during the survey period (EUR $0.29 \mathrm{~L}^{-1}$, [58]) (Table A5).

Differences in electric energy consumed, hourly fuel consumption, $\mathrm{CO}_{2}$ emissions, and economic costs between experimental LED lamps and the traditional incandescent lamp were compared using the same statistical tests applied to the CPUE analysis (Table A5).

\section{Results}

\subsection{Catch Efficiency of LED Lamps}

Experimental catches, obtained from 22 trials, were characterized by high abundances of anchovies, which represent $66 \%$ and $54 \%$ of total catches with LWH and INC, respectively. S. colias, S. pilchardus, the shortfin squid (Illexcoindetii, Ommastrephidae), the swordfish (Xiphias gladius, Xiphiidae), the Atlantic bonito (Sarda sarda, Scombridae), and the horse mackerel (Trachurus mediterraneus, Carangidae) were the main bycatch species detected in the survey (Table 1).

Considering the 20 experimental trials selected for the comparison analysis, the highest time activity of the lighting systems was detected for the LWH ( $68 \mathrm{~h})$, followed by the INC ( $38 \mathrm{~h}$ ), the LBLU (32 h), and the PULSE (16 h) (Table A1). In addition, the electrical energy consumption showed the highest value for the INC $(1023 \mathrm{kWh})$, followed by the LWH $(649 \mathrm{kWh})$, the PULSE $(99 \mathrm{kWh})$, and the LBLU $(81 \mathrm{kWh})$ (Table A5). Moreover, the highest total fuel consumption was detected for the INC (339 L), and then the LWH (181 L), the PULSE (28 L), and the LBLU (26 L). The highest anchovy catch was observed for the LWH (39.1 $\mathrm{t}$ ), followed by the INC (22.2 $\mathrm{t}$ ), and the LBLU and the PULSE, both with about $17.0 \mathrm{t}$. Among these 20 trials, anchovy catches corresponded to about $98 \%$ of the total for each lighting system (Table 1 ).

Considering the catch efficiency, the CPUE per energy consumption of LBLU (median value of $177 \mathrm{~kg} \mathrm{kWh}^{-1}, \mathrm{IR}=59.60$ ) was significantly higher than that of INC (median value of $18 \mathrm{~kg} \mathrm{kWh}^{-1}, \mathrm{IR}=15.30 ; \mathrm{U}=7, p<0.001$ ) and LWH (median value of $42 \mathrm{~kg} \mathrm{kWh}^{-1}$, $\mathrm{IR}=62.04 ; \mathrm{U}=19, p<0.001$ ) (Figure $4 \mathrm{a}$ and Table A6). Moreover, the PULSE (median value of $111 \mathrm{~kg} \mathrm{kWh}^{-1}, \mathrm{IR}=165.44$ ) together with LWH proved to be significantly more efficient than INC ( $U=3, p<0,05 ; U=75, p<0.05$, respectively). Similar differences were observed for the CPUE per fuel consumption, where that of LBLU (median value of $593 \mathrm{~kg} \mathrm{~L}^{-1}$, $\mathrm{IR}=233.48$ ) was significantly higher than INC (median value of $62 \mathrm{~kg} \mathrm{~L}^{-1}, \mathrm{IR}=70.80 ; \mathrm{U}=9$, $p<0.001$ ) and LWH (median value of $159 \mathrm{~kg} \mathrm{~L}^{-1}, \mathrm{IR}=219.73$; $\mathrm{U}=30, p<0.01$ ) (Figure $4 \mathrm{~b}$ and Table A6). In addition, the median CPUE of INC was significantly lower than LWH $\left(\mathrm{U}=70, p<0.01\right.$ ) and PULSE (median value of $392 \mathrm{~kg} \mathrm{~L}^{-1}$, IR = 585.93; $\mathrm{U}=3, p<0.05$ ). 

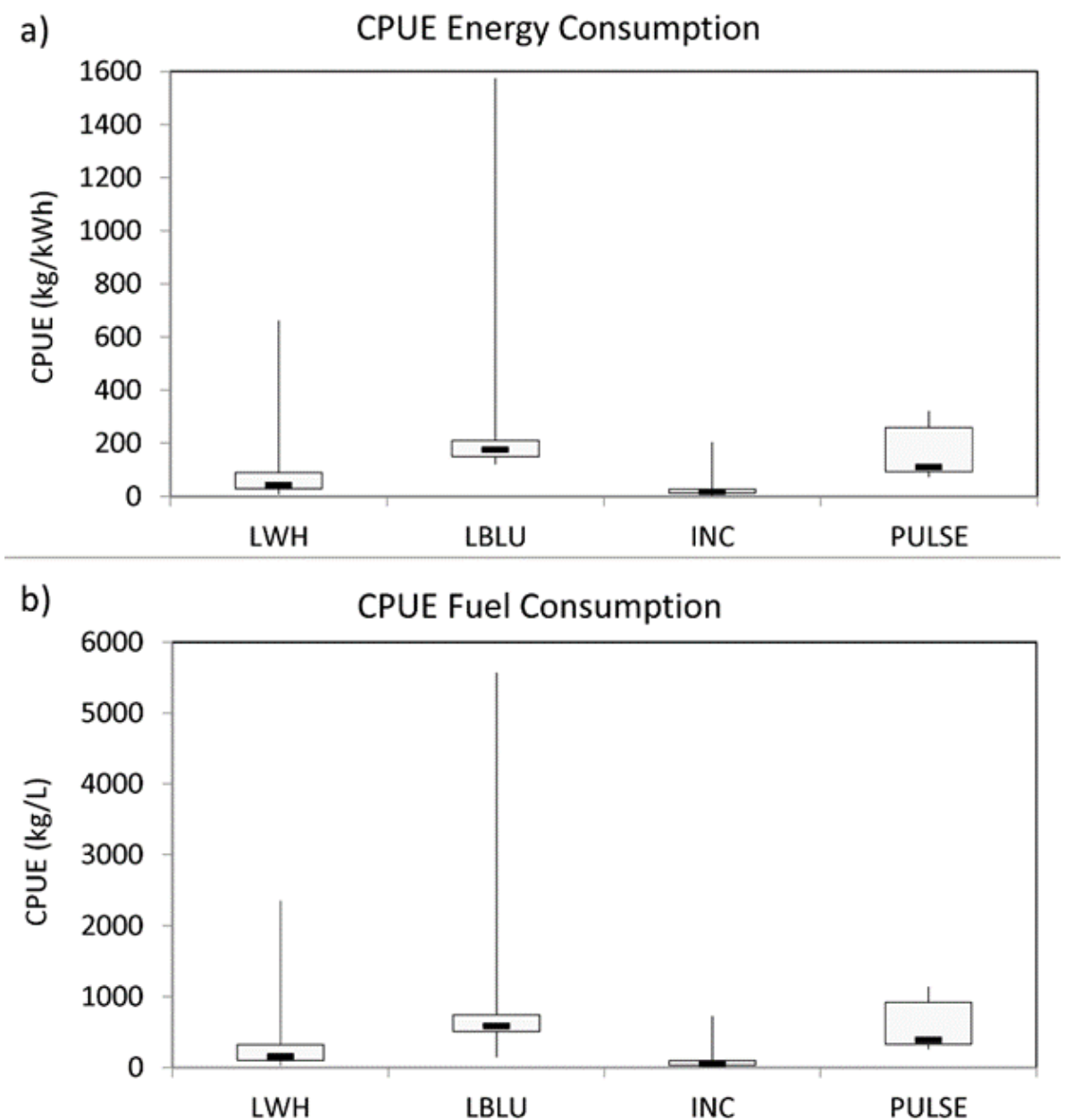

Figure 4. Catch per unit effort (CPUE) calculated in (a) energy consumed $\left(\mathrm{kg} \mathrm{kWh}^{-1}\right)$ and (b) fuel consumption (kg fuel $\mathrm{L}^{-1}$ ) for each LED tested (White, LWH; Blue, LBLU; Pulsing, PULSE) and incandescent lamp (INC).

All anchovy samples (Tot. N. ind. $=2969)$ obtained using the lighting systems showed the same median TL $(136 \mathrm{~mm})$, while the interquartile range of the LWH $(\mathrm{IR}=9 \mathrm{~mm})$ was wider than LBLU and the INC lamps (both IR $=7 \mathrm{~mm}$ ) (Table A3). The min-max TL ranges calculated for the LWH, the LBLU, and the INC lamp were equal to $80-153 \mathrm{~mm}$, 93-175 mm, and 83-156 mm, respectively. All sampled specimens showed the minimum TL value as higher than the size at first maturity. A total of 2957 specimens (LWH N. ind. = 1128; LBLU N. ind. = 740; INC N. ind. = 1089) were selected for the statistical analysis on length-frequency distributions, excluding outliers. The length-frequency distribution of anchovy collected using LWH resulted in significantly different values from those using LBLU $(\mathrm{D}=0.116, p<0.001)$ and INC $(\mathrm{D}=0.094, p<0.001)$, while no difference was observed between LBLU and INC (Figure 5a and Table A6).

Age $1+$ anchovies $(\mathrm{N}$. ind. $=2555)$ were the most frequent specimens by significant amounts in all lighting systems, representing over $85 \%$ of the total $(p<0.05)$, while specimens of Age $2+(\mathrm{N}$. ind. $=402)$ accounted for $14 \%$ of the total (Figure $5 \mathrm{~b}$ and Table A7). No significant difference in $\mathrm{F} \%$ was observed between Age 1+ anchovies sampled by the LWH $(\mathrm{N}$. ind. $=985,33 \%)$, the LBLU $(\mathrm{N}$. ind. $=641,22 \%)$, or the INC $(\mathrm{N}$. ind. $=929,31 \%$ ). 


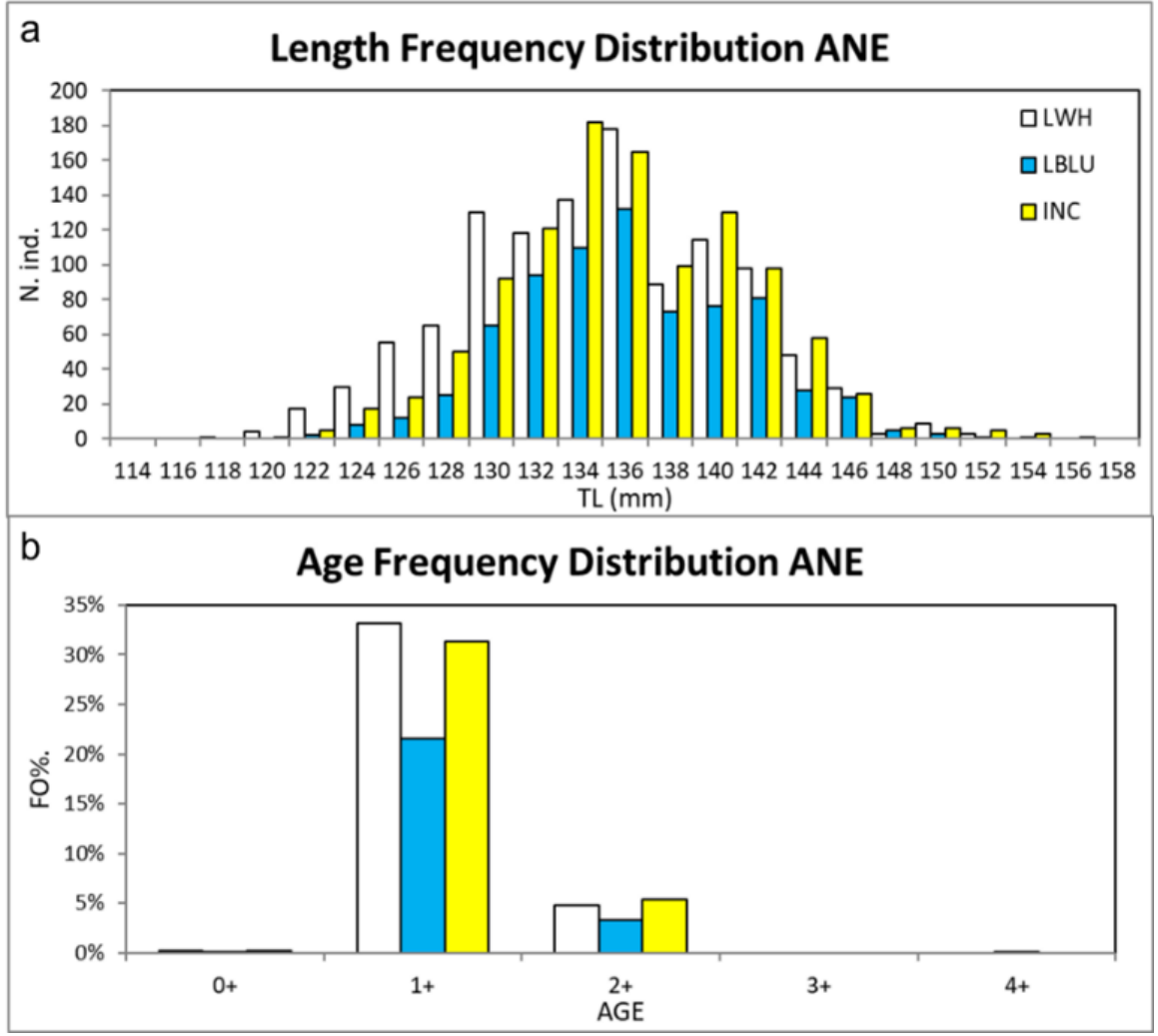

Figure 5. (a) Length-frequency distribution (LFD) of the total length (TL in $\mathrm{mm}$ ) and (b) age frequency distribution calculated for the anchovies (ANE) sampled using LWH, LBLU, and INC. Outliers of TL values, out of the range $114-159 \mathrm{~mm}$, were excluded from the plot.

\subsection{Energy Consumption and $\mathrm{CO}_{2}$ Emissions}

The comparative analysis of hourly fuel consumption showed that the highest median value was measured for INC $\left(7.1 \mathrm{~L} \mathrm{~h}^{-1}, \mathrm{IR}=1.40\right)$, which was significantly higher than $\operatorname{LWH}\left(2.5 \mathrm{~L} \mathrm{~h}^{-1}, \mathrm{IR}=0.66 ; \mathrm{U}=0, p<0.001\right)$, $\operatorname{LBLU}\left(0.7 \mathrm{~L} \mathrm{~h}^{-1}, \mathrm{IR}=0.21 ; \mathrm{U}=0, p<0.001\right)$, and PULSE (1.7 $\mathrm{L} \mathrm{h}^{-1}, \mathrm{IR}=0.04 ; \mathrm{U}=0 ; p<0.01$ ) (Figure 6b, Table A6). Concerning $\mathrm{CO}_{2}$ emissions estimated from fuel consumption, the highest median value was observed for INC (41.4 kg, IR = 37.33) followed by LWH ( $24.1 \mathrm{~kg}$, IR = 25.07), PULSE (14.2 kg, IR = 4.65), and LBLU ( $4.9 \mathrm{~kg}$, IR $=6.14$ ) (Figure $6 \mathrm{c}$ and Table A6). The latter value was significantly lower than for the other lighting systems $(p<0.05$; Table A6).

According to the average fuel price during the survey period, the highest significant hourly cost (median value $2.05 \mathrm{EURh}^{-1}$ ) was estimated for the INC $(p<0.01)$ (Figure $6 \mathrm{~d}$ and Table A6). In addition, the LWH showed a median hourly cost of $0.74 \mathrm{EURh}^{-1}$, which was significantly higher than for the LBLU $\left(0.20 \mathrm{EURh}^{-1}, \mathrm{U}=23 ; p<0.01\right)$ and the PULSE $\left(0.48 \mathrm{EURh}^{-1}, \mathrm{U}=10 ; p<0.05\right)$. Thus, the reduction in costs obtained by using LED systems compared to an incandescent lamp was $64 \%$ and $90 \%$ for both LWH and LBLUE, respectively (Table A5). 

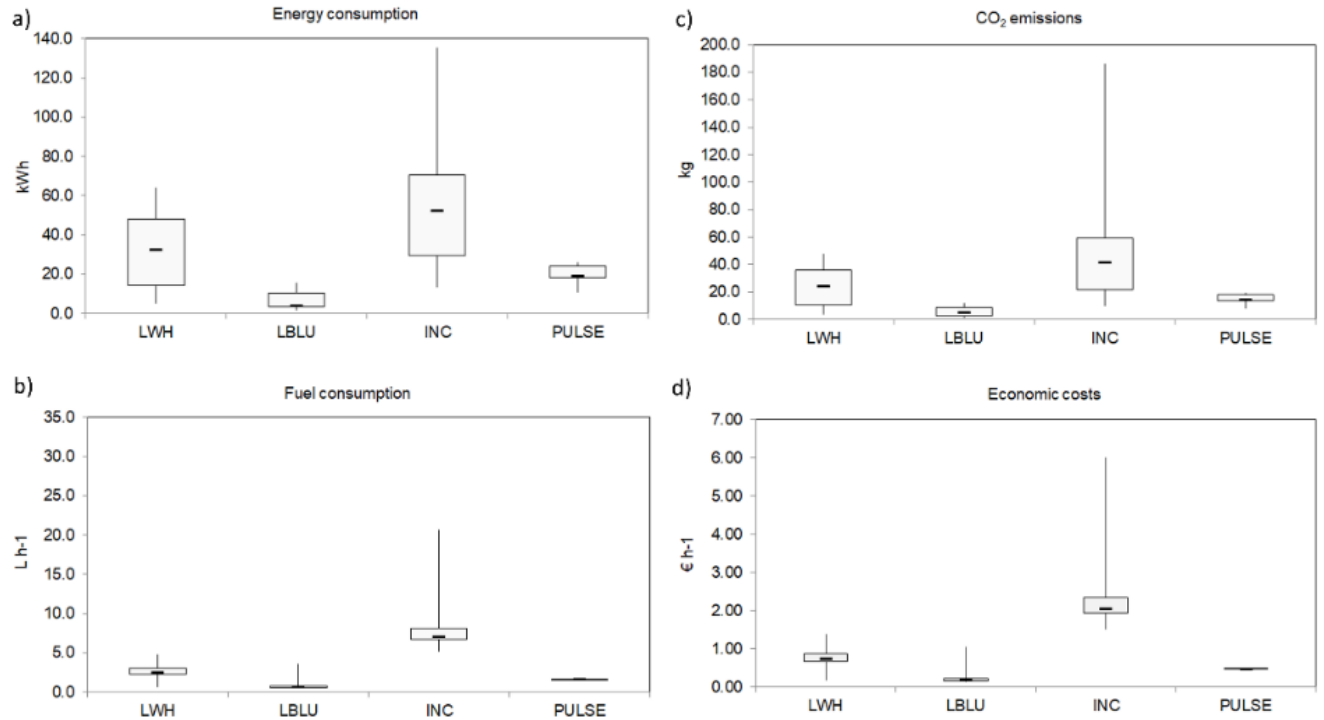

Figure 6. Consumption in terms of (a) energy (kWh), (b) hourly fuel $\left(\mathrm{L} \mathrm{h}^{-1}\right),(\mathbf{c}) \mathrm{CO}_{2}$ emissions (kg), and (d) economic costs (EURh ${ }^{-1}$ ) for each tested LEDs (White, LWH; Blue, LBLU; Pulsing, PULSE) and the incandescent lamp (INC).

\section{Discussion}

The route towards sustainable fisheries management requires an effort in the adoption of the ecosystem-based fishery management approach (EBFM), which is a focal point in the achievement of Goal 14 "Life Below Water" of the Sustainable Development Goals of the United Nations [5]. The holistic approach should be strongly considered in the assessment of the technological advancements in the fishery, focusing on the positive and negative effects induced by catch efficiency changes [13]. Indeed, the temporal increase in catch efficiency (usually indicated as catchability or nominal effort) is not often properly considered in fishery management, with the consequence of making technological innovations applied to reduce the fishing pressure on resources and marine ecosystems ineffective $[8,9]$. In this regard, this study tried to assess the performance of LED technology in the purse seine fishery, providing some indications on the catch efficiency and environmental impacts derived from this innovative fishing device. No less importantly, two of the tested LEDs (blue and pulsing LEDs) were experimented with for the first time in the anchovy fishery, the main commercial species in the Adriatic Sea (central Mediterranean Sea). This choice follows the hypothesis that different-coloured lights could have a greater attraction power for several species, such as blue light [17], or a different setting of lighting systems could reduce both energy and fuel consumption, such as in the case of the pulsing white LED. In addition, the catch quantity and its composition in species observed during the experimental survey are consistent with the landing data from the previous year, validating the procedure adopted in the experimental design and the results.

\subsection{Catch Efficiency of LED Lamps and Biological Aspects}

The results obtained during the survey confirm the possibility of obtaining consistent benefits using the LED lighting systems in terms of yields, which are increased compared to the traditional incandescent lamp. Concerning the catch efficiency of the LED lights, the white LED, which emits light in the same light spectra as the incandescent lamp, increased the yield by over 2 times per consumption unit of energy and fuel. This result is very similar to the estimations reported at the global scale for LED technology applied to the purse seine fishery [17]. It seems likely that the illumination zone produced around the boats by LEDs was more concentrated in a specific direction, increasing the efficiency of attraction, as observed by Nguyen and Tran [22]. Moreover, the yield efficiency increased by values of up to approximately 6 times with the use of the pulsing white LED, as measured using both consumption units. This increase was due to the energy savings resulting from the 
flashing of the LED. Therefore, this setting could be an interesting improvement in the performance, but further studies are required to understand the effective benefits of this LED light configuration. The highest catch efficiency was estimated for the blue LED, which showed yields of over 9 times higher than the incandescent lamp. This higher efficiency of LEDs could be explained by the increase in the concentration of light in the illumination area [22], and by the effect of different wavelengths. Indeed, the greater attraction of blue light (wavelength $465 \mathrm{~nm}$ ), due to its higher water penetration [59], has also been observed for some rockfish species (Sebastes spp.) in Japanese waters [60] and for the fishery of the snow crab (Chionoecetes opilio) in the province of Newfoundland and Labrador, Canada [61]. Further studies should be carried out to quantify the attraction effects on different species and the effective increase in the light penetration in water. In addition, results obtained from the analysis of length-frequency distributions highlighted similar performances in the size of anchovies selected by the LED systems and by the incandescent lamp, with the same median total length value equal to $13.6 \mathrm{~cm}$. Remarkably, these values of total length and the interquartile ranges were abundantly higher than the first maturity size of anchovy in the Adriatic Sea, indicating the absence of impacts of LED systems on immature specimens (TL $<8 \mathrm{~cm},[51])$. A slight difference was observed between the LFD of the LWH and those of other systems, where the former LED seemed to catch a higher number of small specimens (TL range 120-130 mm) than other systems. A possible explanation could still be linked to the higher water penetration of LBLU and the distribution pattern of the anchovy juveniles and adults along the bathymetric gradient. In fact, the depth is an important factor for the habitat selection and Giannoulaki et al. [62] reported a wider movement of the adults towards deep habitats up to $180 \mathrm{~m}$ in depth in late autumn, while juveniles were distributed in shallower waters. Moreover, a similar distribution pattern of juveniles and adults along the depths has been observed in the Bay of Biscay, where within the juvenile component, the smaller specimens also tended to be aggregated near the surface, while larger specimens were located at greater depths [63]. However, further experiments should be performed collecting more samples to assess the effective size selectivity of LED systems and exploring potential influences of seasonality on migrating species [64], as well as other environmental factors acting on different life stages of the anchovy [65].

\subsection{Energy Consumption and $\mathrm{CO}_{2}$ Emissions: Benefits and Critical Points}

Estimates obtained for hourly fuel consumption and $\mathrm{CO}_{2}$ emissions stressed the potential advantages derived from using LEDs in the reduction of the carbon footprint due to the PS fishery. Remarkably, $\mathrm{CO}_{2}$ emission estimates for the incandescent lamp were 1.7 and 2.9 times higher than those for the white and pulsing LED, respectively. In addition, the incandescent lamp emitted GHG amounts over 8 times greater than the blue LED, which again showed the best performances. From these outlines it can be estimated that a PS vessel, working with a traditional gear configuration in the Adriatic Sea, generates an average of $5 \mathrm{t}$ of $\mathrm{CO}_{2}$ per year during the fishing operations using an incandescent lamp, while emissions could decrease below $3500 \mathrm{t}$ per year by adopting the white LED. These estimates could be used to develop scenarios on the GHG emissions of the overall fleet operating in the study area, matching the information related to the nominal fishing effort [59]. Indeed, global analysis on GHG emissions generated by world fisheries indicated that a reduction in the fishery's carbon footprint depends on several factors, among which are the increase in catches, the fishing capacity, and effort [66]. The evaluation of the economic costs highlighted the positive impacts derived from LED technology on the operational costs of the PS fishery, with the fuel cost-saving percentages all being higher than $60 \%$. This estimated value for LWH (64\%) in our experiment was very similar to those obtained in experiments conducted between LED and fluorescent lamps (67\% savings) in Vietnam [22] and between LED and metal halide lamps (64\% savings) in the PS fleet of Indonesia [20]. However, a complete economic assessment should be performed considering device maintenance and fixed costs, to identify when the financial breaking point could be reached, thus obtaining profits for the fishing enterprise [67]. 
Although LED technology provides clear economic and environmental benefits, there are some issues regarding the exploitation of fishery stocks that should be further explored in the evaluation of LED performance. Indeed, the high catch efficiency could induce an increase in the fishing mortality of these fishing resources. Consequently, an unsustainable fishing pressure could affect small pelagic stocks, which are considered in a condition of overexploitation in the Adriatic basin [35,51]. In particular, the increase in catch efficiency due to technological advancements should be managed, considering the nominal effort (or other factors) to balance possible higher fishing pressure [13]. To date, regulations on the power of lights have been adopted in the Spanish purse seine fleet, with limitations of the maximum luminous intensity to 100,000 lumens, as well as requests for replacement of those lights with low energy consumption systems [68]. Therefore, the application of such regulations should take into account both the knowledge of the characteristics of purse seining in the Adriatic Sea and the management strategies of the small pelagic stocks that can best be adapted to achieve sustainable exploitation [69].

\section{Conclusions}

In conclusion, the LED technologies developed and applied in this study clearly show potential benefits at the economic level for the fishermen and the possibility of mitigating indirect negative effects on the environment due to fuel combustion and GHG emissions. Although the results obtained showed clear benefits, the application of new technology to improve the catch efficiency of fishing gears should be carefully considered, with particular attention being paid to a key element in the sustainability of the fisheries [70]. The lack of regulation of fishing activities, as well as the absence of technologically advanced control in fishery management plans, could cause unwanted long-term effects. Therefore, the introduction of innovative fishing devices with a resultant increase in catch-efficiency performance can be effectively realized by adopting the EBFM approach to sustainability.

Author Contributions: Conceptualization: R.C., P.R. and N.T.; formal analysis: P.R., N.T. and D.C.; funding acquisition: R.C.; investigation: P.R., G.C., D.C. and R.C.; project administration: R.C., N.T. and V.T.O.; writing-original draft: P.R., N.T. and D.C.; writing-review and editing: R.C., N.T., D.C., V.T.O. and G.C. All authors have read and agreed to the published version of the manuscript.

Funding: This publication was funded thanks to the Apulia Region within the project "Se.Le.Ca.: Selective LED Catch and Antimicrobial blue light treatment" Research Program PO FEAMP 2014/2020 mis. 1.26 cod. $0002 / \mathrm{INP} / 17$.

Institutional Review Board Statement: Not applicable.

Informed Consent Statement: Not applicable.

Data Availability Statement: Data are available in the final report of the Se.Le.Ca project: Carlucci R., Trivellin N., Orlandi V.T., Meneghesso G., Meliadò E., Cipriano G., Cascione D., Rositani L., Tursi A., Capezzuto F., Piva F., Pizzolato A., Bolognese F., Lombardi G., Ricci P. (2021). Se.Le.Ca.: Selective LED Catch and Antimicrobial blue light treatment. Relazione tecnica, $95 \mathrm{pp}$. Programma PO FEAMP 2014/2020 mis. 1.26 cod. 0002/INP/17.

Acknowledgments: This publication was funded thanks to the Apulia Region within the project "Se.Le.Ca.: Selective LED Catch and Antimicrobial blue light treatment" Research Program PO FEAMP 2014/2020 mis. 1.26 cod. 0002/INP/17. The Authors thank the crew of the purse seine vessel used to conduct the experimental survey.

Conflicts of Interest: The authors declare that they have no conflict of interest. 


\section{Appendix A}

Table A1. Data collected in experimental trials (Tr.): date, latitude (Lat), and longitude (Long), depth (in m), the start time of boats release (R. start time), start and end fishing time, and the time activity (TA in hours minutes) for each LED tested (white, LWH; blue, LBLU; pulsing, PULSE) and the incandescent lamp (INC).

\begin{tabular}{|c|c|c|c|c|c|c|c|c|c|c|c|}
\hline Tr. & Date & Lat & Long & Depth (m) & $\begin{array}{l}\text { R. Start } \\
\text { Time }\end{array}$ & F. Start Time & F. End Time & $\begin{array}{c}\text { TA LWH } \\
\text { (h.m) }\end{array}$ & $\begin{array}{l}\text { TA LBLU } \\
\text { (h.m) }\end{array}$ & $\begin{array}{c}\text { TA INC } \\
\text { (h.m) }\end{array}$ & $\begin{array}{l}\text { TA PULSE } \\
\text { (h.m) }\end{array}$ \\
\hline 1 & $06 / 09 / 20$ & $41^{\circ} 28,906$ & $016^{\circ} 53,428$ & 117 & $20: 18$ & $00: 25$ & $00: 42$ & 4.24 & & 3.00 & \\
\hline 2 & $07 / 09 / 20$ & $41^{\circ} 29,160$ & $017^{\circ} 01,140$ & 143 & $20: 23$ & $23: 06$ & $23: 24$ & 3.01 & & 2.00 & \\
\hline 3 & $10 / 09 / 20$ & $42^{\circ} 62,104$ & $014^{\circ} 51,525$ & 110 & 00:05 & $03: 25$ & $03: 47$ & 3.42 & & 2.15 & \\
\hline 4 & $14 / 09 / 20$ & $43^{\circ} 02,843$ & $014^{\circ} 50,629$ & 114 & $20: 13$ & $21: 08$ & $21: 23$ & 1.00 & & 0.30 & \\
\hline 5 & $14 / 09 / 20$ & $43^{\circ} 01,701$ & $014^{\circ} 49,559$ & 110 & $01: 20$ & 02:08 & $02: 26$ & 0.38 & & 0.19 & \\
\hline 6 & $15 / 09 / 20$ & $43^{\circ} 05,115$ & $014^{\circ} 43,587$ & 515 & $20: 45$ & 03:41 & $03: 58$ & 6.32 & 5.38 & 5.25 & \\
\hline 7 & $15 / 09 / 20$ & $43^{\circ} 05,120$ & $014^{\circ} 43,590$ & 115 & $04: 20$ & 04:55 & $05: 20$ & 0.39 & 0.36 & 0.35 & \\
\hline 8 & $16 / 09 / 20$ & $42^{\circ} 47,711$ & $014^{\circ} 29,308$ & 123 & $20: 51$ & 01:58 & $02: 14$ & 4.39 & 4.50 & 3.38 & \\
\hline 9 & $17 / 09 / 20$ & $42^{\circ} 46,102$ & $014^{\circ} 29,301$ & 121 & $02: 25$ & 03:30 & 03:55 & 1.55 & 1.08 & 0.31 & \\
\hline 10 & $17 / 09 / 20$ & $42^{\circ} 46,444$ & $014^{\circ} 29,095$ & 121 & 04:02 & $05: 56$ & $06: 10$ & 1.50 & 1.55 & 0.30 & \\
\hline 11 & $20 / 09 / 20$ & $42^{\circ} 43,946$ & $014^{\circ} 35,706$ & 149 & $21: 17$ & $02: 35$ & $02: 52$ & 5.35 & 4.56 & 4.11 & \\
\hline 12 & $21 / 09 / 20$ & $42^{\circ} 43,940$ & $014^{\circ} 35,688$ & 150 & 03:12 & 04:15 & $04: 27$ & 0.47 & 1.15 & 0.34 & \\
\hline 13 & $21 / 09 / 20$ & $42^{\circ} 43,830$ & $014^{\circ} 35,522$ & 148 & $04: 45$ & $06: 12$ & $06: 25$ & 1.22 & 1.24 & 0.50 & \\
\hline 14 & $21 / 09 / 20$ & $42^{\circ} 44,856$ & $014^{\circ} 36,340$ & 155 & $22: 50$ & $03: 52$ & $04: 10$ & 5.03 & 4.39 & 3.42 & \\
\hline 15 & $22 / 09 / 20$ & $42^{\circ} 44,558$ & $014^{\circ} 36,470$ & 149 & 04:30 & $06: 20$ & $06: 34$ & 1.43 & 1.56 & 1.13 & \\
\hline 16 & $22 / 09 / 20$ & $42^{\circ} 31,345$ & $014^{\circ} 45,900$ & 138 & $22: 45$ & $02: 50$ & 03:05 & 4.03 & 4.20 & 3.15 & \\
\hline 17 & $22 / 09 / 20$ & $42^{\circ} 27,316$ & $014^{\circ} 46,533$ & 117 & 04:15 & $05: 45$ & 06:02 & 0.56 & 1.47 & 0.40 & \\
\hline 20 & $19 / 10 / 20$ & $42^{\circ} 56,422$ & $014^{\circ} 30,508$ & 115 & 21:40 & $05: 15$ & $06: 30$ & 6.30 & & 3.01 & 4.06 \\
\hline 21 & $20 / 10 / 20$ & $42^{\circ} 35,507$ & $014^{\circ} 38,600$ & 107 & 21:30 & $02: 30$ & $03: 30$ & 4.50 & & & 3.02 \\
\hline 22 & $21 / 10 / 20$ & $43^{\circ} 09,930$ & $014^{\circ} 40,745$ & 97 & $23: 10$ & $03: 40$ & 04:00 & 1.50 & & & 1.50 \\
\hline
\end{tabular}


Table A2. Monthly landing ( $\mathrm{kg}$ ) by species and fishing days in 2019 of the experimental PS vessel in the GSA 17-18. Species are indicated by FAO code: E. encrasicolus (ANE), S. colias (MAS), I. coindetii (SQM), S pilchardus (PIL), X. gladius (SWO), T. thynnus (BFT), and T. mediterraneus (HMM). In June, the PS vessel operated in the GSA 19, thus data are not reported.

\begin{tabular}{|c|c|c|c|c|c|c|c|}
\hline Month & ANE & PIL & MAS & BFT & HМM & SWO & $\begin{array}{c}\text { Fishing } \\
\text { Days }\end{array}$ \\
\hline January & 27,440 & 231 & & & & & 6 \\
\hline February & 15,642 & & & & & & 4 \\
\hline March & 1084 & & & & & & 1 \\
\hline April & 49,875 & 1575 & & 782 & & 33 & 10 \\
\hline May & 25,900 & & & & & 40 & 5 \\
\hline July & 38,534 & 924 & 11,134 & & & & 14 \\
\hline August & 53,605 & 770 & 7861 & & & 64 & 16 \\
\hline September & 44,065 & 1264 & 11,515 & & & & 12 \\
\hline October & 63,510 & 2310 & 33,080 & & & 85 & 18 \\
\hline November & 13,160 & 468 & 3360 & & 2450 & & 6 \\
\hline December & 20,090 & 1750 & 70 & & & & 7 \\
\hline Total & 35,2905 & 9292 & 67,020 & 782 & 2450 & 222 & 99 \\
\hline
\end{tabular}

Table A3. Number of specimens by class size in total length (TL in $\mathrm{mm}$ ) measured for each sample obtained using lighting systems (left side); and age, expressed as number of individuals and \% estimated from TL. Main statistics were calculated to identify TL outliers (see the main text for details).

\begin{tabular}{|c|c|c|c|}
\hline TL & LWH & LBLU & INC \\
\hline 80 & 2 & 0 & 0 \\
\hline 82 & 1 & 0 & 1 \\
\hline 84 & 0 & 0 & 0 \\
\hline 86 & 1 & 0 & 0 \\
\hline 88 & 0 & 0 & 1 \\
\hline 90 & 1 & 0 & 0 \\
\hline 92 & 0 & 1 & 1 \\
\hline 94 & 0 & 0 & 1 \\
\hline 96 & 0 & 0 & 0 \\
\hline 98 & 0 & 0 & 1 \\
\hline 118 & 1 & 0 & 0 \\
\hline 120 & 4 & 0 & 1 \\
\hline 122 & 17 & 2 & 5 \\
\hline 124 & 30 & 8 & 17 \\
\hline 126 & 55 & 12 & 24 \\
\hline 128 & 65 & 25 & 50 \\
\hline 130 & 130 & 65 & 92 \\
\hline 132 & 118 & 94 & 121 \\
\hline 134 & 137 & 110 & 182 \\
\hline 136 & 178 & 132 & 165 \\
\hline
\end{tabular}


Table A3. Cont.

\begin{tabular}{|c|c|c|c|}
\hline TL & LWH & LBLU & INC \\
\hline 138 & 89 & 73 & 99 \\
\hline 140 & 114 & 76 & 130 \\
\hline 142 & 98 & 81 & 98 \\
\hline 144 & 48 & 28 & 58 \\
\hline 146 & 29 & 24 & 26 \\
\hline 148 & 3 & 5 & 6 \\
\hline 150 & 9 & 3 & 6 \\
\hline 152 & 3 & 1 & 5 \\
\hline 154 & 0 & 1 & 3 \\
\hline 156 & 0 & 0 & 1 \\
\hline 174 & 0 & 1 & 0 \\
\hline \multicolumn{4}{|c|}{ Main statistics and TL outliers } \\
\hline & LWH & LBLU & INC \\
\hline Total N. individuals & 1133 & 742 & 1094 \\
\hline Min & 80 & 93 & 83 \\
\hline Max & 153 & 175 & 156 \\
\hline Median & 136 & 136 & 136 \\
\hline I quartile & 131 & 133 & 133 \\
\hline III quartile & 140 & 140 & 140 \\
\hline IR & 9 & 7 & 7 \\
\hline Outliers upper limit (TL mm) & 159 & 154 & 154 \\
\hline Outliers lower limit (TL mm) & 114 & 119 & 119 \\
\hline AGE & LWH & LBLU & INC \\
\hline Age $0+$ N. $(\%)$ & $5(0.2 \%)$ & $1(<0.1 \%)$ & $5(0.2 \%)$ \\
\hline Age $1+$ N. $(\%)$ & $985(33.2 \%)$ & $641(21.6 \%)$ & $929(31.2 \%)$ \\
\hline Age $2+$ N. $(\%)$ & $143(4.8 \%)$ & $99(3.3 \%)$ & $160(5.4 \%)$ \\
\hline Age 3+ N. (\%) & - & - & - \\
\hline Age $4+$ N. $(\%)$ & - & $1(<0.1 \%)$ & - \\
\hline
\end{tabular}

Table A4. Normality test (Shapiro-Wilk, W) applied to CPUEs, energy, and hourly fuel consumptions, $\mathrm{CO}_{2}$ emissions compared among each lighting system, and the length-frequency distribution (LFD) of anchovy obtained by the LWH, LBLU, and INC. Significant $p$ values $(<0.05)$ in red indicate a non-normal distribution of data.

\begin{tabular}{ccccc}
\hline Normality Test: Shapiro-Wilk (W) & LWH & LBLU & INC & PULSE \\
\hline N. samples & 20 & 12 & 18 & 5 \\
\hline CPUE Energy, W: & 0.507 & 0.403 & 0.483 & 0.846 \\
\hline$p$ value & $<0.001$ & $<0.01$ & $<0.001$ & 0.1818 \\
\hline CPUE Fuel, W: & 0.511 & 0.439 & 0.485 & 0.846 \\
\hline$p$ value & $<0.001$ & $<0.01$ & $<0.001$ & 0.1818 \\
\hline Electric Energy Consumption, $\mathrm{W}:$ & 0.905 & 0.8484 & 0.9419 & 0.9425 \\
\hline$p$ value & 0.050 & $<0.05$ & 0.312 & 0.684 \\
\hline
\end{tabular}


Table A4. Cont.

\begin{tabular}{ccccc}
\hline Normality Test: Shapiro-Wilk (W) & LWH & LBLU & INC & PULSE \\
\hline Hourly Fuel Consumption, W: & 0.926 & 0.431 & 0.697 & 0.943 \\
\hline$p$ value & 0.1282 & $5.71 \mathrm{E}-03$ & $7.42 \mathrm{E}-02$ & 0.685 \\
\hline $\mathrm{CO}_{2}$ Emissions, W: & 0.911 & 0.877 & 0.789 & 0.942 \\
\hline$p$ value & 0.066 & 0.081 & $<0.01$ & 0.682 \\
\hline Economic Costs, W: & 0.925 & 0.443 & 0.695 & 0.821 \\
\hline$p$ value & 0.121 & $<0.001$ & $<0.001$ & 0.119 \\
\hline LFD & LWH & LBLU & INC & - \\
\hline N. samples & 1128 & 739 & 1086 & - \\
\hline LFD LWH sample, W & 0.9946 & 0.9931 & 0.9944 & - \\
\hline$p$ value & $<0.001$ & $<0.01$ & $<0.001$ & - \\
\hline
\end{tabular}

Table A5. Energy, fuel consumption, and hourly costs of each lighting system tested in the 20 experimental trials (Tr.) selected for the statistical analysis.

\begin{tabular}{|c|c|c|c|c|c|c|c|c|c|c|c|c|}
\hline \multirow[b]{2}{*}{ Tr. } & \multicolumn{4}{|c|}{ Energy Consumption (kWh) } & \multicolumn{4}{|c|}{ Fuel Consumption (L) } & \multicolumn{4}{|c|}{ Economic Costs (EUR $\left.h^{-1}\right)$} \\
\hline & LWH & LBLU & INC & PULSE & LWH & LBLU & INC & PULSE & LWH & LBLU & INC & PULSE \\
\hline 1 & 56.7 & & 74.9 & & 16.0 & & 21.2 & & 1.05 & & 2.05 & \\
\hline 2 & 32.7 & & 52.3 & & 9.2 & & 14.8 & & 0.89 & & 2.14 & \\
\hline 3 & 31.8 & & 58.8 & & 9.0 & & 16.6 & & 0.70 & & 2.14 & \\
\hline 6 & 63.8 & 15.6 & 135.3 & & 18.0 & 4.4 & 38.2 & & 0.80 & 0.23 & 2.05 & \\
\hline 7 & 5.3 & 1.8 & 13.3 & & 1.5 & 0.5 & 3.7 & & 0.67 & 0.24 & 1.86 & \\
\hline 8 & 46.4 & 11.7 & 70.4 & & 11.7 & 3.3 & 70.4 & & 0.73 & 0.20 & 5.62 & \\
\hline 9 & 14.4 & 2.9 & 28.1 & & 2.9 & 4.1 & 7.9 & & 0.44 & 1.04 & 4.45 & \\
\hline 10 & 16.8 & 3.5 & 36.6 & & 4.7 & 1.0 & 10.3 & & 0.75 & 0.15 & 6.00 & \\
\hline 11 & 47.0 & 9.7 & 99.0 & & 13.3 & 2.7 & 28.0 & & 0.69 & 0.16 & 1.94 & \\
\hline 12 & 13.3 & 3.2 & 29.3 & & 3.8 & 0.9 & 8.3 & & 1.39 & 0.21 & 4.23 & \\
\hline 13 & 10.8 & 4.0 & 19.8 & & 3.1 & 1.1 & 5.6 & & 0.65 & 0.23 & 1.94 & \\
\hline 14 & 50.9 & 11.7 & 109.1 & & 14.4 & 3.3 & 30.8 & & 0.83 & 0.21 & 2.41 & \\
\hline 15 & 19.5 & 4.0 & 30.4 & & 5.5 & 1.1 & 8.6 & & 0.93 & 0.17 & 2.05 & \\
\hline 16 & 42.5 & 9.2 & 81.2 & & 12.0 & 2.6 & 22.9 & & 0.86 & 0.17 & 2.05 & \\
\hline 17 & 14.2 & 3.5 & 16.7 & & 4.0 & 1.0 & 4.7 & & 1.25 & 0.16 & 2.05 & \\
\hline 18 & 52.3 & & 45.2 & 19.0 & 14.8 & & 12.8 & 5.4 & 0.75 & & 1.52 & 0.47 \\
\hline 19 & 60.5 & & 62.2 & 26.2 & 17.1 & & 17.6 & 7.4 & 0.63 & & 1.60 & 0.47 \\
\hline 20 & 14.4 & & 60.2 & 24.4 & 4.1 & & 17.0 & 6.9 & 0.18 & & 1.63 & 0.49 \\
\hline 21 & 39.8 & & & 18.1 & 11.2 & & & 5.1 & 0.67 & & & 0.49 \\
\hline 22 & 15.6 & & & 10.8 & 4.4 & & & 3.0 & 0.70 & & & 0.48 \\
\hline Median & 32.2 & 4.0 & 55.5 & 19.0 & 9.1 & 1.9 & 15.7 & 5.4 & 0.74 & 0.20 & 2.05 & 0.48 \\
\hline IR & 33.58 & 6.82 & 44.25 & 6.24 & 9.5 & 2.3 & 14.1 & 1.8 & & & & \\
\hline Min & 5.3 & 1.8 & 13.3 & 10.8 & 1.5 & 0.5 & 3.7 & 3.0 & 0.18 & 0.15 & 1.52 & 0.47 \\
\hline Max & 63.8 & 15.6 & 135.3 & 26.2 & 18.0 & 4.4 & 70.4 & 7.4 & 1.39 & 1.04 & 6.00 & 0.49 \\
\hline $\begin{array}{l}\text { Reduction costs } \\
\text { vs. INC } \\
\text { (median value) }\end{array}$ & & & & & & & & & -1.31 & -1.84 & - & -1.56 \\
\hline $\begin{array}{l}\text { Reduction costs } \\
\text { vs. INC }(\%)\end{array}$ & & & & & & & & & 64 & 90 & & 76 \\
\hline
\end{tabular}


Table A6. Mann-Whitney test (U) applied to the CPUEs ( $\mathrm{kg} \mathrm{kWh}^{-1}$ and $\mathrm{kg} \mathrm{L}^{-1}$ ), energy consumption $(\mathrm{kWh})$, hourly fuel consumption $\left(\mathrm{L} \mathrm{h}^{-1}\right), \mathrm{CO}_{2}$ emissions $(\mathrm{kg})$, and economic costs $\left(\mathrm{EUR}^{-1}\right)$ of all lighting systems. Kolmogorov-Smirnov test (D) applied to the length-frequency distribution (LFD) of anchovy sampled by LWH, LBLU, and INC systems. U/D values and $p$ values are below and above the diagonal of each table, respectively. Significant $p$ values are indicated in red.

\begin{tabular}{|c|c|c|c|c|c|c|c|c|c|}
\hline \multicolumn{10}{|c|}{ U Test } \\
\hline $\begin{array}{l}\text { CPUE Energy } \\
\text { Consumption }\end{array}$ & LWH & LBLU & INC & PULSE & $\begin{array}{l}\text { CPUE Fuel } \\
\text { Consumption }\end{array}$ & LWH & LBLU & INC & PULSE \\
\hline LWH & - & $<0.001$ & $<0.05$ & 0.194 & LWH & - & $<0.01$ & $<0.01$ & 0.194 \\
\hline LBLU & 19 & - & $<0.001$ & 1 & LBLU & 30 & - & $<0.001$ & 1 \\
\hline INC & 75 & 7 & - & $<0.05$ & INC & 70 & 9 & - & $<0.05$ \\
\hline PULSE & 18 & 22 & 3 & - & PULSE & 18 & 25 & 3 & - \\
\hline $\begin{array}{c}\text { Energy } \\
\text { Consumption }\end{array}$ & LWH & LBLU & INC & PULSE & $\begin{array}{l}\text { Hourly Fuel } \\
\text { Consumption }\end{array}$ & LWH & LBLU & INC & PULSE \\
\hline LWH & - & $<0.001$ & 0.1207 & 1 & LWH & - & $<0.01$ & $<0.001$ & $<0.05$ \\
\hline LBLU & 12 & - & $<0.001$ & $<0.05$ & LBLU & 25.5 & - & $<0.001$ & 0.054 \\
\hline INC & 100 & 1 & - & 0.061 & INC & 0 & 0 & - & $<0.01$ \\
\hline PULSE & 35 & 3 & 10 & - & PULSE & 10 & 5 & 0 & - \\
\hline $\mathrm{CO}_{2}$ Emissions & LWH & LBLU & INC & PULSE & Economic Costs & LWH & LBLU & INC & PULSE \\
\hline LWH & - & $<0.001$ & 0.095 & 1.00 & LWH & & $<0.01$ & $<0.001$ & $<0.05$ \\
\hline LBLU & 20 & - & $<0.05$ & $<0.05$ & LBLU & 23 & & $<0.001$ & 0.057 \\
\hline INC & 97 & 2 & - & 0.061 & INC & 0 & 0 & & $<0.05$ \\
\hline PULSE & 36.5 & 4 & 10 & - & PULSE & 10 & 5 & 0 & \\
\hline \multicolumn{10}{|c|}{ D Test } \\
\hline LFD & LWH & LBLU & INC & & & & & & \\
\hline N. samples & 1128 & 739 & 1086 & & & & & & \\
\hline LWH & - & $<0.001$ & $<0.001$ & & & & & & \\
\hline LBLU & 0.116 & - & 0.869 & & & & & & \\
\hline INC & 0.094 & 0.032 & - & & & & & & \\
\hline
\end{tabular}

Table A7. U test applied to the age-frequency distribution of anchovies for LWH, LBLU, and INC systems. U values and $p$ values are below and above the diagonal of each table, respectively. Significant $p$ values $(<0.05)$ are in red.

\begin{tabular}{|c|c|c|c|c|c|c|c|c|c|c|}
\hline & & \multicolumn{3}{|c|}{ LWH } & \multicolumn{3}{|c|}{ LBLU } & \multicolumn{3}{|c|}{ INC } \\
\hline & & Age 0+ & Age 1+ & Age 2+ & Age 0+ & Age 1+ & Age 2+ & Age 0+ & Age 1+ & Age 2+ \\
\hline \multirow{3}{*}{ LWH } & Age 0+ & & $<0.001$ & 0.870 & 1.000 & $<0.001$ & 1.000 & 1.000 & $<0.001$ & 0.870 \\
\hline & Age 1+ & 3350 & & $<0.001$ & $<0.001$ & 1.000 & $<0.001$ & $<0.001$ & 1.000 & $<0.001$ \\
\hline & Age 2+ & 4750 & 3600 & & 0.870 & $<0.05$ & 1.000 & 0.870 & $<0.001$ & 1.000 \\
\hline \multirow{3}{*}{ LBLU } & Age 0+ & 4750 & 3350 & 4750 & & $<0.001$ & 1.000 & 1.000 & $<0.001$ & 0.870 \\
\hline & Age 1+ & 3900 & 4450 & 4150 & 3900 & & $<0.01$ & $<0.001$ & 1.000 & $<0.05$ \\
\hline & Age 2+ & 4850 & 3500 & 4900 & 4850 & 4050 & & 1.000 & $<0.001$ & 1.000 \\
\hline \multirow{3}{*}{ INC } & Age 0+ & 4850 & 3350 & 4750 & 4850 & 3900 & 4850 & & $<0.001$ & 0.870 \\
\hline & Age 1+ & 3450 & 4900 & 3700 & 3450 & 4550 & 3600 & 3450 & & $<0.001$ \\
\hline & Age 2+ & 4750 & 3600 & 5000 & 4750 & 4150 & 4900 & 4750 & 3700 & \\
\hline
\end{tabular}




\section{References}

1. Worm, B.; Hilborn, R.; Baum, J.K.; Branch, T.A.; Collie, J.S.; Costello, C.; Fogarty, M.J.; Fulton, E.A.; Hutchings, J.A.; Jennings, S.; et al. Rebuilding Global Fisheries. Science 2009, 325, 578-584. [CrossRef]

2. Teh, L.C.L.; Sumaila, U.R. Contribution of marine fisheries to worldwide employment. Fish Fish. 2013, 14, 77-88. [CrossRef]

3. Golden, C.D.; Allison, E.H.; Cheung, W.W.; Dey, M.M.; Halpern, B.S.; McCauley, D.J.; Smith, M.; Vaitla, B.; Zeller, D.; Myers, S.S. Nutrition: Fall in fish catch threatens human health. Nature 2016, 534, 317-320. [CrossRef]

4. $\quad$ Stephenson, R.L.; Paul, S.; Wiber, M.; Angel, E.; Benson, A.J.; Charles, A.; Sumaila, U.R. Evaluating and implementing socialecological systems: A comprehensive approach to sustainable fisheries. Fish Fish. 2018, 19, 853-873. [CrossRef]

5. Duarte, C.M.; Agusti, S.; Barbier, E.; Britten, G.L.; Castilla, J.C.; Gattuso, J.-P.; Boris, W. Rebuilding marine life. Nature 2020, 580, 39-51. [CrossRef]

6. Pikitch, E.K.; Santora, C.; Babcock, E.A.; Bakun, A.; Bonfil, R.; Conover, D.O.; Dayton, P.; Doukakis, P.; Fluharty, D.; Heneman, B.; et al. Ecosystem-Based Fishery Management. Science 2004, 305, 346-347. [CrossRef]

7. Hornborg, S.; van Putten, I.; Novaglio, C.; Fulton, E.A.; Blanchard, J.L.; Plagányi, E.; Bulman, C.; Sainsbury, K. Ecosystem-based fisheries management requires broader performance indicators for the human dimension. Mar. Policy 2019, 108, 103639. [CrossRef]

8. Eigaard, O.R.; Marchal, P.; Gislason, H.; Rijnsdorp, A.D. Technological Development and Fisheries Management. Rev. Fish. Sci. Aquac. 2014, 22, 156-174. [CrossRef]

9. Palomares, M.L.D.; Pauly, D. On the creeping increase of vessels' fishing power. Ecol. Soc. 2019, 24, 31. [CrossRef]

10. Costello, C.; Ovando, D.; Clavelle, T.; Strauss, C.K.; Hilborn, R.; Melnychuk, M.C.; Branch, T.A.; Gaines, S.D.; Szuwalski, C.S.; Cabral, R.B.; et al. Global fishery prospects under contrasting management regimes. Proc. Natl. Acad. Sci. USA 2016, 113, 5125-5129. [CrossRef]

11. Pauly, D.; Zeller, D. Catch reconstructions reveal that global marine fisheries catches are higher than reported and declining. Nat. Commun. 2016, 7, 10244. [CrossRef]

12. Hilborn, R.; Amoroso, R.O.; Anderson, C.M.; Baum, J.K.; Branch, T.A.; Costello, C.; De Moor, C.L.; Faraj, A.; Hively, D.; Jensen, O.P.; et al. Effective fisheries management instrumental in improving fish stock status. Proc. Natl. Acad. Sci. USA 2020, 117, 2218-2224. [CrossRef]

13. Scherrer, K.; Galbraith, E. Regulation strength and technology creep play key roles in global long-term projections of wild capture fisheries. ICES J. Mar. Sci. 2020, 77, 2518-2528. [CrossRef]

14. Driscoll, J.; Tyedmers, P. Fuel use and greenhouse gas emission implications of fisheries management: The case of the new England Atlantic herring fishery. Mar. Policy 2010, 34, 353-359. [CrossRef]

15. Chassot, E.; Antoine, S.; Guillotreau, P.; Lucas, J.; Assan, C.; Marguerite, M.; Bodin, M.N. Fuel consumption and air emissions in one of the world's largest commercial fisheries. Environ. Pollut. 2021, 273, 116454. [CrossRef]

16. Ben-Yami, M. The Role of Small-Scale Fishing Gear and Techniques in Development: Challenges Towards the Year 2000. In Proceedings of the World Symposium on Fishing Gear and Fishing Vessel Design, St. John's, NL, Canada, 20-24 November 1988; Marine Institute: St. John's, NL, Canada, 1989; pp. 449-453.

17. Nguyen, K.Q.; Winger, P.D. Artificial Light in Commercial Industrialized Fishing Applications: A Review. Rev. Fish. Sci. Aquac. 2019, 27, 106-126. [CrossRef]

18. Ben-Yami, M. Fishing with Light-FAO fishing manuals, Farnham, Surrey, England. Int. Rev. Entire Hydrobiol. Hydrogr. 1978, 63, 585. [CrossRef]

19. Ben-Yami, M. Purse Seining Manual. In FAO Fishing Manual; Fishing News Book: Oxford, UK, 1990.

20. Sofijanto, M.A.; Arfiati, D.; Lelono, T.D.; Muntaha, A. Efficiency comparison of LED and MH lamps in purse seine fisheries. Turk. J. Fish. Aquat. Sci. 2019, 19, 41-49. [CrossRef]

21. Thuy, P.T.T.; Flaaten, O.; Anh, N.T.K. Remuneration System and Economic Performance: Theory and the Vietnamese Small Scale Fisheries. Mar. Resour. Econ. J. 2013, 28, 19-41.

22. Nguyen, K.Q.; Tran, P.D. Benefits of using LED light for purse seine fisheries: A case study in Ninhthuan province, Vietnam. Fish People 2015, 13, 30-36.

23. An, H.C. Research on Artificial Light Sources for Light Fishing, with a Focus on Squid Jigging. In Proceedings of the Symposium on the Light Session and the Topic Group Lights: ICES-FAO Working Group on Fishing Technology and Fish, Bangkok, Thailand 6-10 May 2013; FAO: Rome, Italy, 2015; pp. 49-50.

24. Okamoto, K. Intelligent non-conventional applications of LEDs. J. Japan Inst. Electron. Packag. 2010, 3, 116-123. [CrossRef]

25. Mills, E.; Gengnagel, T.; Wollburg, P. Solar-LED alternatives to fuel-based lighting for night fishing. Energy Sustain. Dev. 2014, 21, 30-41. [CrossRef]

26. An, Y.I.; He, P.; Arimoto, T.; Jang, U.J. Catch performance and fuel consumption of LED fishing lamps in the Korea hairtail angling fishery. Fish. Sci. 2017, 83, 343-352. [CrossRef]

27. Yamashita, Y.; Matsushita, Y.; Azuno, T. Catch performance of coastal squid jigging boats using LED panels in combination with metal halide lamps. Fish. Res. 2012, 113, 182-189. [CrossRef]

28. Weyl, O.; Kazembe, J.; Booth, A.; Mandere, D. An assessment of a light-attraction fishery in southern Lake Malawi. Afr. J. Aquat. Sci. 2004, 29, 1-11. [CrossRef]

29. Mgana, H.; Kraemer, B.M.; O’Reilly, C.M.; Staehr, P.A.; Kimirei, I.A.; Apse, C.; Leisher, C.; Ngoile, M.; McIntyre, P.B. Adoption and consequences of new light-fishing technology (LEDs) on Lake Tanganyika, East Africa. PLoS ONE 2019, 14, e0216580. [CrossRef] 
30. Papaconstantinou, C.; Farrugio, H. Fisheries in the Mediterranean. Mediterr. Mar. Sci. 2000, 1, 5-18. [CrossRef]

31. Tsitsika, E.V.; Maravelias, C.D. Fishing strategy choices of purse seines in the Mediterranean: Implications for management. Fish Sci. 2008, 74, 19-27. [CrossRef]

32. Tsagarakis, K.; Vassilopoulou, V.; Kallianiotis, A.; Machias, A. Discards of the purse seine fishery targeting small pelagic fish in the eastern Mediterranean Sea. Sci. Mar. 2012, 76, 561-572. [CrossRef]

33. Cingolani, N.; Giannetti, G.; Arneri, E. Anchovyfisheries in the Adriatic Sea. Sci. Mar. 1996, 60, $269-277$.

34. Santojanni, A.; Arneri, E.; Barry, C.; Belardinelli, A.; Cingolani, N.; Giannetti, G.; Kirkwood, G. Trends of anchovy (Engraulisencrasicolus L.) biomass in the northern and central Adriatic Sea. Sci. Mar. 2003, 67, 327-340. [CrossRef]

35. Carpi, P.; Santojanni, A.; Donato, F.; Colella, S.; ČikešKeč, V.; Zorica, B.; Leonori, I.; De Felice, A.; Tičina, V.; Modic, T.; et al. A joint stock assessment for the anchovy stock of the northern and central Adriatic Sea: Comparison of two catch-at-age models. Sci. Mar. 2015, 79, 57-70. [CrossRef]

36. Farrugio, H.; Soldo, A.; Cebrian, D.; Requena, S. Adriatic Sea: Status and Conservation of Fisheries; RAC/SPA: Tunis, Tunisia, 2015; p. 58.

37. Virgili, M.; Vasapollo, C.; Lucchetti, A. Can ultraviolet illumination reduce sea turtle bycatch in Mediterranean set net fisheries? Fish. Res. 2018, 199, 1-7. [CrossRef]

38. Lucchetti, A.; Bargione, G.; Petetta, A.; Vasapollo, C.; Virgili, M. Reducing Sea Turtle Bycatch in the Mediterranean Mixed Demersal Fisheries. Front. Mar. Sci. 2019, 6, 387. [CrossRef]

39. Kehayias, G.; Bouliopoulos, D.; Chiotis, N.; Koutra, P. A photovoltaic-battery-LED lamp raft design for purse seine fishery: Application in a large Mediterranean lake. Fish. Res. 2016, 177, 18-23. [CrossRef]

40. Marini, M.; Russo, A.; Paschini, E.; Grilli, F.; Campanelli, A. Short-term physical and chemical variations in the bottom water Middle Adriatic depressions. Clim. Res. 2006, 31, 227-237. [CrossRef]

41. Zavatarelli, M.; Raicich, F.; Bregant, D.; Russo, A.; Artegiani, A. Climatological biogeochemical characteristic of the Adriatic Sea. J. Mar. Syst. 1998, 18, 227-263. [CrossRef]

42. Vrgoc, N.; Arneri, E.; Jukic-Peladic, S.; Krstulovic-Sifner, S.; Mannini, P.; Marceta, B.; Osmani, K.; Piccinetti, C.; Ungaro, N. Review of Current Knowledge on Shared Demersal Stocks of the Adriatic Sea. ADRIAMED Tech. Doc. 2004, 12, 91.

43. Lleonart, J.; Maynou, F. Fish stock assessments in the Mediterranean: State of the art. Sci. Mar. 2003, 67, 37-49. [CrossRef]

44. European Comission. Facts and Figures on the Common Fishery Policy; Publication Office of the European Union: Luxembourg, 2016.

45. Marano, G. Small Pelagic stock assessment (1984-1996). In Proceedings of the Working Group on the Definition of Priority Topics Related to Shared Small Pelagic Fishery Resources of the Adriatic Sea 1st Meeting, (Adriatic Sea Shared Stocks), Split, Croatia, 12-13 October 2000. ADRIAMED Tech. Doc. 2001, 3, 66-77.

46. Palomera, I.; Olivar, M.; Salat, J.; Sabatés, A.; Coll, M.; García, A.; Morales-Nin, B. Small pelagic fish in the NW Mediterranean Sea: An ecological review. Prog. Oceanogr. 2007, 74, 377-396.

47. Zorica, B.; Vilibić, I.; Keč, V.C.; Šepić, J. Environmental conditions conducive to anchovy (Engraulisencrasicolus) spawning in the Adriatic Sea. Fish. Oceanogr. 2013, 22, 32-40. [CrossRef]

48. Grbec, B.; Jakov, D.; Morović, M. Long-term changes in landings of small pelagic fish in the eastern Adriatic-Possible influence of climate oscillations over the Northern Hemisphere. Clim. Res. 2002, 20, 241-252. [CrossRef]

49. Santojanni, A.; Arneri, E.; Bernardini, V.; Cingolani, N.; Marco, M.; Russo, A. Effects of environmental variables on recruitment of anchovy in the Adriatic Sea. Clim. Res. 2006, 31, 181-193. [CrossRef]

50. Carpi, P.; Scarcella, G.; Cardinale, M. The Saga of the Management of Fisheries in the Adriatic Sea: History, Flaws, Difficulties, and Successes toward the Application of the Common Fisheries Policy in the Mediterranean. Front. Mar. Sci. 2017, 4, 423. [CrossRef]

51. SA-GFCM. Stock Assessment on Small Pelagics in GSA 17.18; Report 2021; General Fisheries Commission for the Mediterranean (GFCM): Rome, Italy, 2021; p. 6.

52. Press, W.H.; Teukolsky, S.A.; Vetterling, W.T.; Flannery, B.P. Numerical Recipes in C, 2nd ed.; Cambridge University Press: Cambridge, UK, 1992; pp. 623-626.

53. McDonald, J.H. Handbook of Biological Statistics, 3rd ed.; Sparky House Publishing: Baltimore, MD, USA, 2014.

54. Shapiro, S.S.; Wilk, M.B. An analysis of variance test for normality (complete samples). Biometrika 1965, 52, 591-611. [CrossRef]

55. Hammer, Ø.; Harper, D.A.T.; Ryan, P.D. PAST: Paleontological Statistics Software Package for Education and Data Analysis. Palaeontol. Electron. 2001, 4, 4-9.

56. EPA, United States Environmental Protection Agency. Available online: https://www.epa.gov/ (accessed on 4 October 2021).

57. ISO 3675. Available online: https://www.iso.org/standard/23626.html (accessed on 4 October 2021).

58. BMTI, Borsa Merci Telematica Italiana. Analisi Trimestrale sui Prezzi e Sul Mercato dei Prodotti della Pesca e Dell'acquacoltura. MiPAAF. 2021. Available online: https: / /ittico.bmti.it/Prezzi/pages / Archivio?tipo=trimestrale\&anno=2021 (accessed on 14 December 2021).

59. FAO. Report of the Symposium on Impacts of Fishing on the Environment ICES-FAO Working Group on Fishing Technology and Fish Behaviors; Food and Agriculture Organization of the United Nations: Rome, Italy, 2015.

60. Sakamoto, M.; Fujimori, Y.; Matsubara, N.; Yasuma, H.; Shimizu, S.; Katakura, S. Fish attracting effects of led light of different colours. Contributions on the Theory of Fishing Gears and Related Marine Systems. In Proceedings of the 13th International Workshop on Methods for the Development and Evaluation of Maritime Technologies, Sapporo, Japan, 2-4 October 2017. 
61. Nguyen, Q.K.; Winger, P.D.; Morris, C.; Grant, S.M. Artificial lights improve the catchability of snow crab (Chionoecetesopilio) traps Aquac. Fish. 2017, 2, 124-133. [CrossRef]

62. Giannoulaki, M.; Iglesias, M.; Tugores, M.P.; Bonanno, A.; Patti, B.; De Felice, A.; Leonori, I.; Bigot, J.L.; Tičina, V.; Pyrounaki, M.M.; et al. Characterizing the potential habitat of European anchovy Engraulisencrasicolus in the Mediterranean Sea, at different life stages. Fish. Oceanogr. 2013, 22, 69-89. [CrossRef]

63. Boyra, G.; Peña, M.; Cotano, U.; Irigoien, X.; Rubio, A.; Nogueira, E. Spatial dynamics of juvenile anchovy in the Bay of Biscay. Fish. Oceanogr. 2016, 25, 529-543. [CrossRef]

64. O'Boyle, R.; Dean, M.; Legault, C.M. The influence of seasonal migrations on fishery selectivity. ICES J. Mar. Sci. 2016, 73, 1774-1787. [CrossRef]

65. Fernández-Corredor, E.; Albo-Puigserver, M.; Pennino, M.G.; Bellido, J.M.; Coll, M. Influence of environmental factors on different life stages of European anchovy (Engraulisencrasicolus) and European sardine (Sardinapilchardus) from the Mediterranean Sea. Reg. Stud. Mar. Sci. 2021, 41, 101606. [CrossRef]

66. Parker, R.W.R.; Blanchard, J.L.; Gardner, C.; Green, B.S.; Hartmann, K.; Tyedmers, P.H.; Watson, R.A. Fuel use and greenhouse gas emissions of world fisheries. Nat. Clim. Change 2018, 8, 333-337. [CrossRef]

67. Nguyen, K.Q.; Tran, P.D.; Nguyen, L.T.; To, P.V.; Morris, C.J. Use of light-emitting diode (LED) lamps in combination with metal halide (MH) lamps reduce fuel consumption in the Vietnamese purse seine fishery. Aquac. Fish. 2021, 6, 432-440. [CrossRef]

68. Order Arm/2529/2011, of 21 September, Which Regulates Fishing with Purse Seines in the Mediterranean Fishery Arts. Available online: https:/ / www.boe.es/buscar/doc.php?id=BOE-A-2011-15094 (accessed on 14 December 2021).

69. Fiorentino, F.; Vitale, S. How Can We Reduce the Overexploitation of the Mediterranean Resources? Front. Mar. Sci. 2021, 8 , 674633. [CrossRef]

70. Squires, D.; Vestergaard, N. Technical change in fisheries. Mar. Policy 2013, 42, 286-292. [CrossRef] 